\title{
Microvascular Experimentation in the Chick Chorioallantoic Membrane as a Model for Screening Angiogenic Agents including from Gene-Modified Cells
}

\author{
Donna C. Kennedy (D, Barbara Coen, Antony M. Wheatley* ${ }^{(D)}$ and Karl J. A. McCullagh *D
}

check for

Citation: Kennedy, D.C.; Coen, B.; Wheatley, A.M.; McCullagh, K.J.A. Microvascular Experimentation in the Chick Chorioallantoic Membrane as a Model for Screening Angiogenic Agents including from Gene-Modified Cells. Int. J. Mol. Sci. 2022, 23, 452. https://doi.org/10.3390/ ijms23010452

Academic Editor: Victor van Beusechem

Received: 17 December 2021 Accepted: 29 December 2021 Published: 31 December 2021

Publisher's Note: MDPI stays neutral with regard to jurisdictional claims in published maps and institutional affiliations.

Copyright: (c) 2021 by the authors. Licensee MDPI, Basel, Switzerland. This article is an open access article distributed under the terms and conditions of the Creative Commons Attribution (CC BY) license (https:// creativecommons.org/licenses/by/ $4.0 /)$.

\author{
Department of Physiology, School of Medicine, Human Biology Building, National University of Ireland, \\ H91 W5P7 Galway, Ireland; d.kennedy12@nuigalway.ie (D.C.K.); barbara.coen@nuigalway.ie (B.C.) \\ * Correspondence: antony.wheatley@nuigalway.ie (A.M.W.); karl.mccullagh@nuigalway.ie (K.J.A.M.); \\ Tel.: +353-914-92361 (A.M.W.); +353-914-94220 (K.J.A.M.)
}

\begin{abstract}
The chick chorioallantoic membrane (CAM) assay model of angiogenesis has been highlighted as a relatively quick, low cost and effective model for the study of pro-angiogenic and anti-angiogenic factors. The chick CAM is a highly vascularised extraembryonic membrane which functions for gas exchange, nutrient exchange and waste removal for the growing chick embryo. It is beneficial as it can function as a treatment screening tool, which bridges the gap between cell based in vitro studies and in vivo animal experimentation. In this review, we explore the benefits and drawbacks of the CAM assay to study microcirculation, by the investigation of each distinct stage of the CAM assay procedure, including cultivation techniques, treatment applications and methods of determining an angiogenic response using this assay. We detail the angiogenic effect of treatments, including drugs, metabolites, genes and cells used in conjunction with the CAM assay, while also highlighting the testing of genetically modified cells. We also present a detailed exploration of the advantages and limitations of different CAM analysis techniques, including visual assessment, histological and molecular analysis along with vascular casting methods and live blood flow observations.
\end{abstract}

Keywords: chorioallantoic membrane (CAM); angiogenesis; blood flow; cancer; tumour; microcirculation

\section{Introduction}

The appropriate delivery of metabolites and removal of waste products is essential in maintaining tissue homeostasis in the body. For this to occur, the presence of a vast well-connected microvascular blood vessel network is crucial. In the absence of this system, negative effects such as oxygen deprivation and tissue death can occur [1,2]. The microvasculature is also essential for an array of physiological responses including hormone responses and inter-organ communication, and injury responses including immune and inflammatory responses. Angiogenesis is the process by which new blood vessels form from pre-existing vessels, a phenomenon required in normal physiology, development, growth injury and disease [3]. There are two types of angiogenesis, sprouting and intussusceptive angiogenesis. Sprouting angiogenesis is where blood vessels form as a result of sprouts of endothelial cells [4,5]. Intussusceptive angiogenesis was more recently discovered and entails pre-existing blood vessels "splitting" down the middle to form two new branching blood vessels [6]. Angiogenesis is an organised cascade of events, regulated by several pro- and anti-angiogenic growth factors. Pro-angiogenic growth factors include fibroblast growth factor (FGF) [7], vascular endothelial growth factor (VEGF) [8], transforming growth factor- $\alpha$ (TGF- $\alpha)$ [9], TGF- $\beta$ [10], hepatocyte growth factor [11], and tumour necrosis factor$\alpha(\mathrm{TNF} \alpha)$ [12]. However, thrombospondins (TSP) [13], angiostatin [14] and endostatin [15] can lead to anti-angiogenic effects. The growth of new blood vessels is induced by the delicate balance between pro-angiogenic and anti-angiogenic factors [16]. The release of 
these factors activates proteolytic enzymes to remodel the extracellular matrix (ECM) of blood vessels, leading to sprouting and reorganisation of new blood vessels [17].

Cancer therapeutic research and the targeting of VEGF have been major impetuses in expanding interest in angiogenesis in more recent times. Nonetheless, our understanding of these angiogenic factors and signalling pathways are still being investigated and more studies are required to fully explore the understanding of the basic mechanisms, and subsequent translation of this to potential therapeutic use. As a result, the development and standardisation of angiogenic assays, both in vitro and in vivo are vitally important in facilitating this research.

Several angiogenic assays have shown particular benefit in the study of microvascularisation, both in vitro and in vivo. These include in vitro assays such as the use of endothelial cells in culture (migration, proliferation, survival and morphogenesis assays), the rat and mouse aortic ring assays, the embryoid body assay and the mouse metatarsal assay [18-21] Angiogenic in vivo assays include the corneal micro pocket, the rodent mesentery assay, the dorsal skin fold procedure and the use of subcutaneous sponge/matrix plugs in conjunction with rodent models and the chick chorioallantoic membrane (CAM) assay [22-25].

In vivo investigation is often considered to be more informative than in vitro as it accounts for the interaction of several physiological pathways that cannot be mimicked using cell culture. However, issues such as high-cost, ethical approval and animal sacrifice are drawbacks for most in vivo assays. The CAM assay is an underutilised in vivo angiogenic assay, as it is not subject to these aforementioned drawbacks [26,27]. The CAM is a highly vascularised membrane found in fertilized chicken eggs, with a vast vascular network of capillaries, veins and arteries, which can be easily manipulated and observed for experimental study of angiogenesis (Figure 1) [28-30]. The CAM assay can be seen as a bridge which links cell based in vitro studies with in vivo animal experimentation, providing a method to study complex biological procedures while adhering to the "Three R strategy" established by Russell and Burch to reduce animal suffering [31].

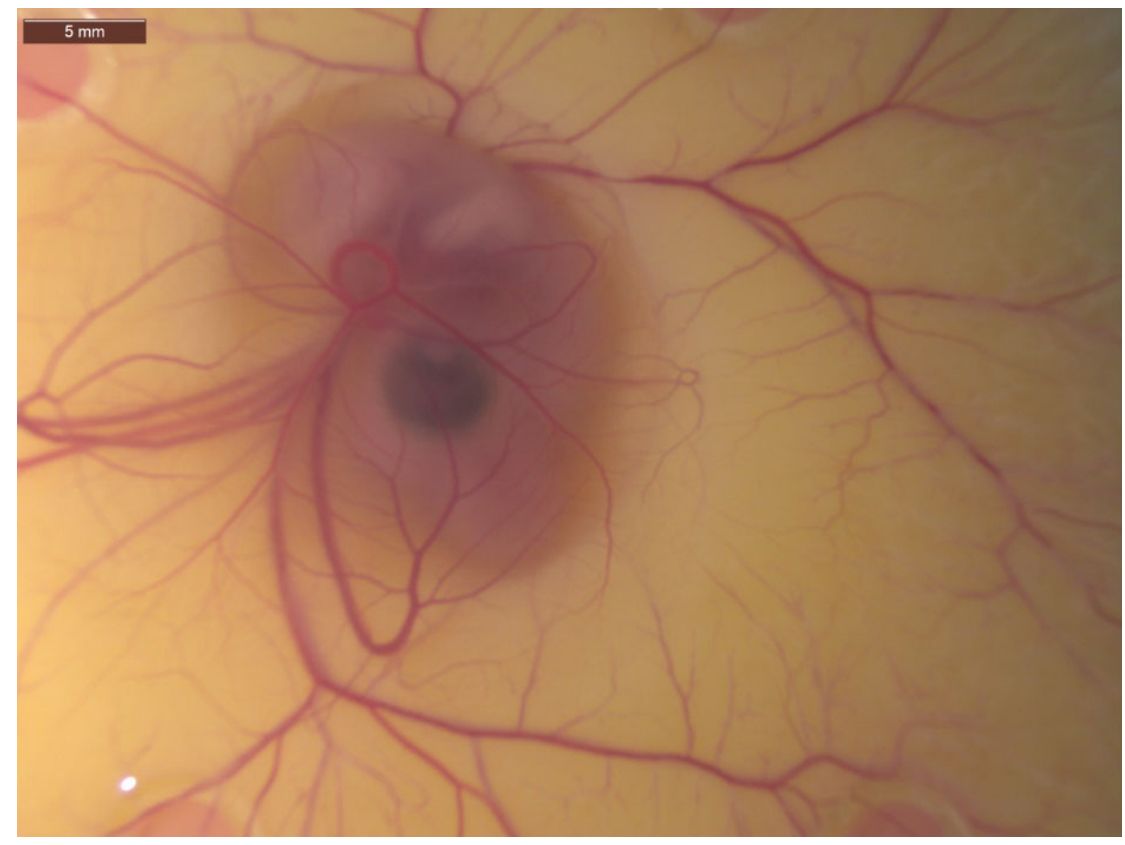

Figure 1. Image of 7-day-old chick embryo with associated chick chorioallantoic membrane (CAM) and its vast vascular network of capillaries, veins and arteries visible. Image taken at $25 \times$ magnification.

\section{CAM and Chick Development}

The CAM is a highly vascularised membrane used for nourishment, gaseous exchange and excretion found in the fertilized eggs of amniotes such as birds and reptiles, analogous to the placenta in mammals $[26,30]$. The CAM consists of three layers, chorionic epithelium, 
the mesenchyme epithelium and the allantoic epithelium, each of which carry out their own specific function [30]. The allantoic membrane, derived from the mesoderm is where the primitive blood vessels and vascularisation develop from day 3 , with the fusion of the chorionic epithelium and allantoic epithelium occurring at day 4 to produce the double layered chorioallantoic membrane [32]. The CAM consists of several ECM proteins such as laminin, collagen type IV and fibronectin, which allow for the mimicking of the normal physiological microenvironment of warm blooded animals, including humans [33].

Hamburger and Hamilton in 1951 characterised the development of the growing chick embryo, carried out by dividing the 21 days of chick development into forty-six distinctive stages [34]. The CAM grows for the latter 15-16 days of development, expanding alongside the chick embryo until day 21 when the embryo cracks the shell and the egg hatches [30]. Until approximately day 12 the growth of the chick embryo and the CAM vascularisation is undergoing accelerated development. Therefore, the efficacy of any pro-angiogenic or anti-angiogenic factor applied up until this time will be heightened [17]. Consequently, it is recommended to carry out angiogenic assays in the days following day 11, where any new blood vessel generation is more likely resulting from the treatment and not the naturally growing chorioallantoic membrane [27,35].

In the absence of a fully developed immune system until development day 18, the CAM is capable of hosting allogeneic or immune-incompetent acellular matrix or tissue graft until this point. Therefore, the CAM is best employed within a limited window of time in order to accurately assess an angiogenic response and avoid immune reactions. [17,30,36].

The understanding of chick and CAM development is essential for its application as an experimental model. The CAM angiogenic assay procedure follows a basic four-stage process: activation, cultivation, treatment and harvest (Figure 2).

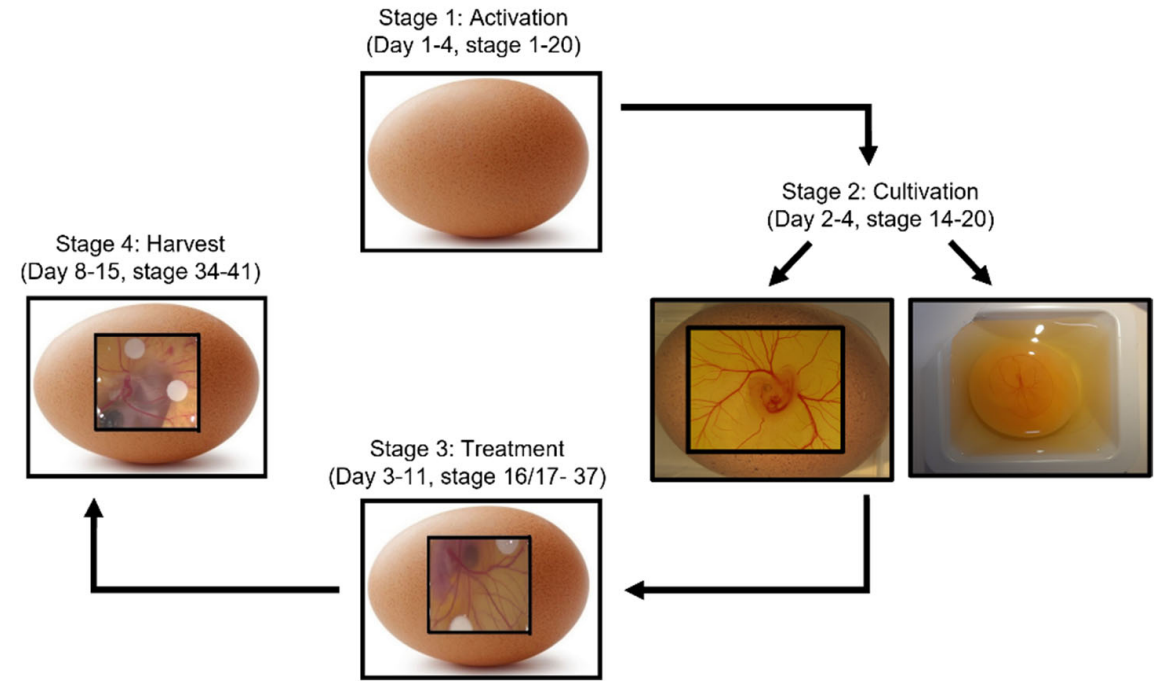

Figure 2. Schematic of four-stage CAM assay process, along with approximate embryonic development days where this stage typically takes place. Stage 1: Activation is where eggs are put in a rotating incubator at $50 \%$ humidity to allow for preliminary development. Stage 2: Cultivation allows for visualisation of the embryo and CAM through either ex ovo cultivation where the eggshell is cracked with contents then transferred into a sterile petri dish, or in ovo cultivation where a saw tool is used to excise a window in the surface of the eggshell. Stage 3: Treatments such as cells, drugs or growth factors are applied. This can be through a variety of methods such as application of on-plants, pipetting directly onto the CAM surface or injection into the CAM vasculature. Finally, upon completion of the experiment, the chick embryo is sacrificed and the CAM is removed for analysis. Analysis can include visual observations of angiogenesis, histological examination, or molecular investigation.

Makanya et al. used light microscopy, ultrastructural analysis and immunohistochemistry to identify and characterise the three specific phases of the 21 day CAM development; 
phase I (day 8-13, stage 34-39), phase II (day 13-18, stage 39-44) and phase III (day 18-20, stage 44-45) with most rapid growth seen in phase I, less in phase II and even regression observed in phase III [30]. This study reinforces ideas previously expressed by Baum et al. where VEGF-A expression in the CAM peaked during various times in these phases triggering intussusceptive angiogenesis [8]. The understanding of these phases of development has to be considered in the design of a CAM angiogenic assay, with inconsistency possibly leading to hyperinflated interpretation of results in relation to the angiogenic responses observed.

\section{CAM Assay Procedures}

In the CAM experimental method, there are two basic processes: In ovo cultivation and ex ovo cultivation, based on the Latin for "in the egg" and "outside the egg" respectively (Figure 3). Initially for both methods, eggs are kept in a humidified incubator at a constant humidity and at a temperature of $37^{\circ} \mathrm{C}$ for the initial days of development before extraction of the shell from the embryo for visualisation [37].

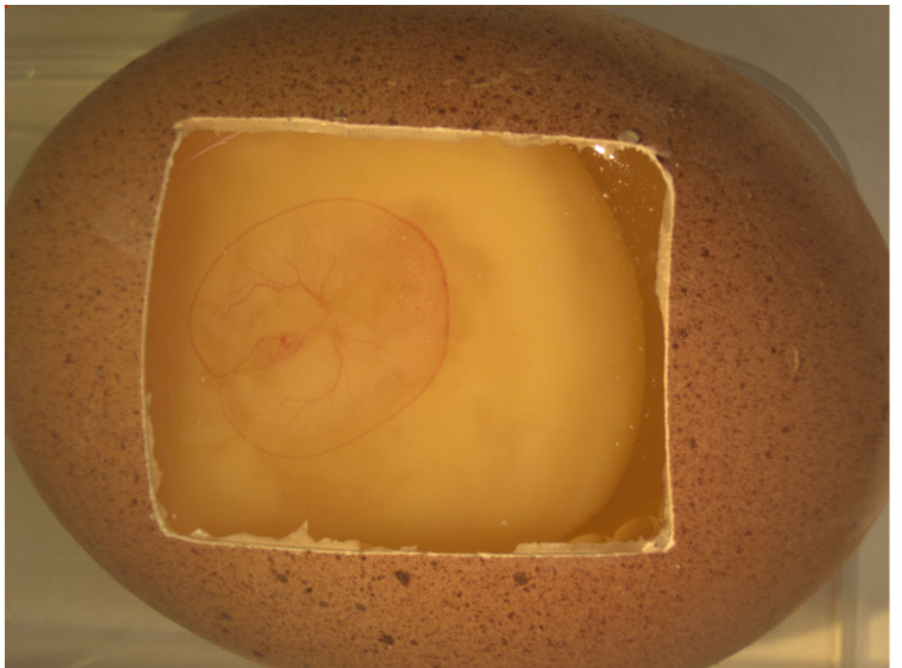

(A)

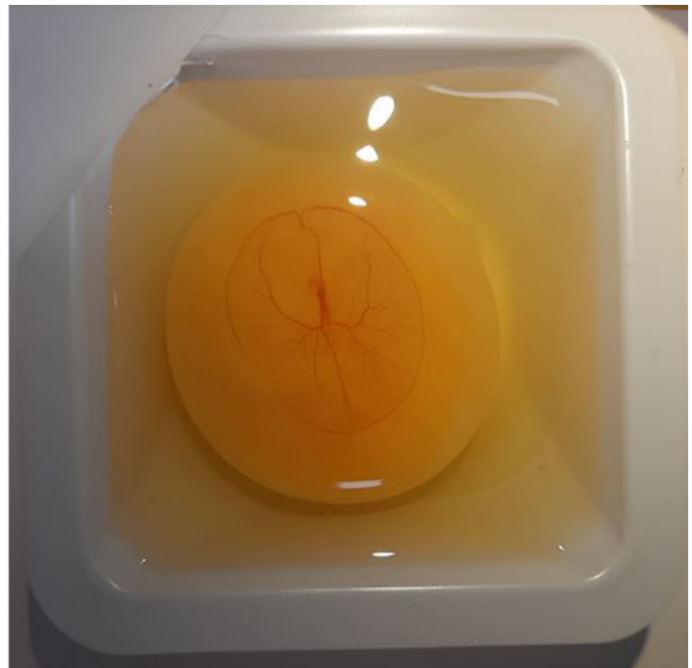

(B)

Figure 3. 4-day old chick embryo and associated chorioallantoic membrane (CAM) following (A) In ovo and (B) Ex ovo cultivation. The CAM expands as the embryo grows. Ex ovo cultivation is beneficial through the larger surface area available for experimentation, however embryo survival is impacted.

In ovo cultivation is where a small hole is created at the apex of the egg and 2-3 $\mathrm{mL}$ of albumin is removed to lower the embryo and CAM away from the eggshell. A mini-saw tool is used to excise a window in the surface of the eggshell. The created window is covered with a sterile laboratory wrap or plastic cover to ensure sterility and maintain humidity [38-40]. The eggs are then returned to a $50-80 \%$ humidified incubator for several days before experimentation can begin. This method of cultivation is minimally invasive on the growing chick embryo, providing a relatively unchanged environment for its growth, and generally improves the survival rate for the experiment.

Alternatively, ex-ovo (also referred to as shell-less cultivation) is where the eggshell is cracked or sawed and the embryo, yolk sac and contents of the egg are transferred to a petri dish, cell culture dish or sterile weigh boat and allowed to develop [28,41]. There are few reports of survival rates of embryos during either in ovo or ex ovo cultivation method. However, Dohle et al. have produced a specialised protocol for optimum survival with ex ovo cultivation, indicating survival rates of $50 \%$ over 14 days [28]. Lokman et al. report survival with in ovo cultivated embryos of $70 \%$ at day 14 [33]. It can be inferred that in ovo shows improved survival compared to shell-less cultivation as it involves less displacement of the embryo, with sterility and humidity issues also reduced. Nonetheless, 
a limitation with in ovo cultivation is that there is reduced visibility and surface area for experimentation compared to the fully exposed embryo on a petri dish [36].

Naik et al. 2018 suggest an alternative, outlining a detailed protocol where instead of a petri dish or weigh boat, the contents of the eggshell are transferred to a cling film pocket suspended in a plastic cup; this method has shown success, with survivability of $>70 \%$ reported while still providing the benefit of larger surface accessibility for experimentation [42]. However, despite this apparent success, no other research group has reported use of this method of cultivation to date.

\section{CAM Experimental Treatments}

The CAM has also proven successful with focus on specific areas of research not limited to angiogenic investigation. Successful assays using the CAM have been developed, including but not limited to metastasis, inflammation and propagation, and the grafting of tumour cells [28]. The application of cells in an engraftment onto a CAM was first successfully carried out in 1913, using sarcoma cells to develop tumour growth [43]. Subsequently, the CAM has been subjected to a myriad of treatments, including modified and un-modified cells, tumours, peptides, proteins, plasmids, micro-RNA (miRNA) and pharmacological agents, drugs, metabolites, biomaterials nanoparticles, plant extracts, and growth factors. These treatments were also applied to the CAM by diverse means involving several different scaffolding techniques [44,45].

\subsection{Scaffolds and Delivery Methods}

CAM assay experiments have been adapted to incorporate a wide variety of scaffolding and treatment methods. Outlined in Table 1 are examples of the various scaffolds used in conjunction with the CAM assay, with both biological and non-biological approaches used. Although the test substance in experimentation is important, consideration should also be taken when choosing a suitable scaffold to support the delivery of the treatment. In 2001, Zwadlo-Klarwasser et al. investigated the angiogenic and inflammatory responses of the various biomaterials often used as scaffolds or supports in conjunction with the CAM assay. This research observed increased angiogenesis and cell infiltration due to an inflammatory response when irregular materials such as collagen or filter paper were applied, compared to smoother substances such as PVC or Tecoflex [46]. Considering this, thought should be given when choosing a scaffold, as confounding or skewed results can occur due to the scaffold used or the mechanical influences such as shear stress or stretch, as well as other forces of certain on-plants themselves can trigger an angiogenic response [47,48]. A solution to this issue is the comparison of different scaffolds for the same treatment, as seen in the work by Mangir et al., 2019, where estradiol treatment is applied both by direct pipetting onto the CAM surface and also by encapsulation in a hydrogel scaffold [49]. However, direct application to the surface may not be feasible with certain treatments, such as non-clustering cells, which may require adequate support for survival, and a suitable scaffold to allow containment of cells to within a localised treatment area [50]. The basement membrane matrix Matrigel has been used frequently to fulfil this role. Matrigel, is a basement-membrane matrix taken from Engelbreth-Holm-Swarm mouse sarcomas, consisting of several ECM proteins such as laminin, collagen, heparan sulfate proteoglycans, entactin/nidogen, and a number of growth factors to support cell survival [51,52]. The Matrigel is liquid below $10^{\circ} \mathrm{C}$, therefore it is pre-cooled to mix with cells, and then applied to the warmer CAM surface where it polymerises encapsulating the cells [50]. However, due to the biologically sourced nature of Matrigel, inconsistencies in composition and mechanical properties can occur both between batches and even within batches. This can lead to issues in experimental reproducibility, therefore it has been suggested a move to synthetic polymer scaffold could be a possible resolution [53]. 
Table 1. Examples of various forms of scaffolds and delivery techniques for a variety of pro angiogenic and anti-angiogenic treatments used on the CAM assay.

\begin{tabular}{cc}
\hline Scaffold/Delivery Method & Reference \\
\hline Collagen & {$[54-57]$} \\
Filter disc & {$[58-65]$} \\
Gelatin sponge & {$[66-71]$} \\
Glass discs & {$[72,73]$} \\
Hydrogel & {$[41,74-77]$} \\
Injected & {$[78-84]$} \\
Matrigel & {$[16,85-90]$} \\
Methylcellulose disc & {$[15,91-94]$} \\
Microspheres & {$[95,96]$} \\
Pipetted onto surface & {$[97-103]$} \\
Plastic ring & {$[75,104-111]$} \\
Scaffold & {$[108,112-117]$} \\
Thermanox coverslip & {$[118-122]$} \\
Tumour & {$[5,123-126]$} \\
Pellet & {$[127-129]$} \\
\hline
\end{tabular}

\subsection{Drugs, Metabolites, miRNAs and Other Treatments}

A wide array of both biological and non-biological treatment options has been developed, optimised and applied successfully to the CAM assay. The term biological can apply to both cell and tissue on-plants, or other factors which come from a living source such as hormones, growth factors, metabolites, miRNA and antibodies, with non-biological treatments usually involving drugs, chemicals or nanoparticles.

Outlined in Table 2 are examples of both biological and non-biological substances which have been applied to the CAM assay and have provided a positive angiogenic response, through increased vasculogenesis and neoangiogenesis. In the case of these proangiogenic treatments, examples of biological substances are seen much more abundantly, with growth factors such as fibroblast growth factor (FGF), transforming growth factor (TGF) and the known pro-angiogenic vascular endothelial growth factor (VEGF) in several isoforms most commonly described.

Wang et al., investigated the precise mechanism growth factor TGF- $\beta$ employs to trigger angiogenesis. In this research, the integral role miRNA-29a has in TGF- $\beta$ induced angiogenesis is explored [130]. MicroRNAs, also known as miRs, are small, non-coding RNA which play a pivotal role in gene regulation [131]. In recent years, it has become evident that miRs play an important role in many cellular processes, including angiogenesis [132]. However, the role miRs have in angiogenic induction or inhibition in the CAM assay has been sparsely investigated. Huan et al., through their research on ameliorating ischaemia in the diabetic foot, have presented and validated a pro-angiogenic miR (miR21-5p), delivered through exomes [133]. MiR-21-5p induces an increase in vascularisation through upregulation of several angiogenic pathways [133]. Similarly, exomes derived from chronic myeloid leukaemia cells [134] and mesenchymal stem cells [133] also result in stimulating angiogenesis in the CAM.

Direct genetic modification of the CAM is an area also not yet fully explored, with few studies applying gene vectors such as plasmids or recombinant viruses. Transfection of an FGF-1 expression plasmid into the CAM induced significant blood vessel growth [135], and the application of a microgel releasing VEGF-GFP lentivirus vector releasing microgels [136], elicited similar effects, as seen in Table 2. 
Table 2. Examples of non-cellular treatments applied to the CAM which elicited a pro-angiogenic response.

\begin{tabular}{c}
\hline Treatment \\
\hline $\begin{array}{c}\text { Connective tissue } \\
\text { growth factor (CTGF) }\end{array}$ \\
Platelet-derived growth
\end{tabular}
factor (PDGF)

Basic Fibroblast Growth Factor (bFGF/FGF-2)

\section{Transforming growth factor- $\beta$ (TGF- $\beta$ )}

$\mathrm{TNF} \alpha$

VEGF-165

VEGF-121

VEGF-A

VEGF-C

Thyroxine

Heparin

VEGF-D

Estradiol
Plastic ring

Delivery Method

Scaffold

Thermanox Coverslips

Thermanox Coverslips

Scaffold

Scaffold

Plastic ring

Filter disc

Filter disc

Filter disc

Filter disc

Hydrogel

Thermanox Coverslips

Thermanox Coverslips

Filter disc

Filter disc

Scaffold

Matrigel

Glass fibre filter disc

Plastic ring

Hydrogel

Hydrogel

Methylcellulose disc

Hydrogel

Hydrogel

Hydrogel

Scaffold

\section{Angiogenic Outcome}

Significant increase in blood vessel number and diameter following software quantification

Ref.

A dose dependent increase seen by appearance of spoke wheel pattern of blood vessels radiating from on-plants

Macroscopic observations indicated thickening of CAM, but no vascular response

An increased blood vessel density converging towards on-plant observed along with thickening of CAM membrane

Significant increase in number of blood vessels converging towards on-plant

Significant increase in mean fluorescent vascular density, measured by pixel intensity

Increased number of branch points in a region around on-plants

[137]

Radial formation of new vessels seen in area around on-plants

Significant increase in tube length and size as measured by angiogenic software

[143]

A dose responsive increase in blood vessels in defined area observed

A time-dependent increase in blood vessel diameter and

branching points, measured using angiogenic software

Macroscopic observations saw a dose dependent increase in angiogenesis

Macroscopic observations noticed a change in vascular pattern under the treatment area

Software quantified a dose responsive increase in total blood vessel network length

Significant increase in sprouting blood vessels within a defined area

Increased blood vessel density observed within a defined area Microvascular mapping of the blood vessel network following

FITC injection resulted in increased blood vessel density Significant increase in vessels number quantified in a random square areas of CAM surface

Angiogenic software indicated a significant increase in number of branchpoints and average vessel length Significant increase in vessel length, number and vasculogenic index

Significant increase in vessel number in a region around on-plant

Significant increase in vessel number in a region around on-plant

Increase in sprouting blood vessels present within a defined area

Significant increase in vascular penetration of on-plants

Significant increase in vessel number in a region around on-plant

Significant increase in sprouting blood vessels present within a defined area

Calculation of percentage of CAM surface covered by endothelial cells resulted in a significant increase in the mean vessels count

Angiogenic software quantified a significant increase in number of branchpoints and average vessel length

Increase in angiogenic response seen by measurement of vasculogenic index 
Table 2. Cont.

\begin{tabular}{|c|c|c|c|}
\hline Treatment & Delivery Method & Angiogenic Outcome & Ref. \\
\hline Estradiol & Filter disc & $\begin{array}{l}\text { Increased vascular branching observed within a defined area } \\
\text { The number of primary, secondary, tertiary, and quaternary }\end{array}$ & [155] \\
\hline L-Arginine & Filter disc & $\begin{array}{l}\text { blood vessels counted with a significant increase in number of } \\
\text { quaternary blood vessels }\end{array}$ & [3] \\
\hline $\begin{array}{l}\text { TGF- } \beta \text { induced } \\
\text { miR-29a upregulation }\end{array}$ & Pipetted & $\begin{array}{c}\text { Significant increase in number of blood vessels around } \\
\text { on-plant observed }\end{array}$ & [130] \\
\hline $\begin{array}{l}\text { Fibroblast growth } \\
\text { factor-1 expression } \\
\text { plasmid }\end{array}$ & Pipetted & $\begin{array}{l}\text { Significant increase in number of blood vessels in a region } \\
\text { around on-plant observed }\end{array}$ & [135] \\
\hline VEGF-GFP LV & Microgels & Increased blood vessel development quantified & [136] \\
\hline $\begin{array}{l}\text { MSCs-exomes } \\
\text { miR-21-5p OE exomes }\end{array}$ & Not mentioned & Significant promotion of new blood vessel formation & [133] \\
\hline Transthyretin & Plastic ring & $\begin{array}{c}\text { Significant increase in number of blood vessels growing } \\
\text { towards on-plants }\end{array}$ & [110] \\
\hline Terbutaline & Plastic disc & $\begin{array}{c}\text { Counting blood vessels which intersected a concentric circle } \\
\text { projected around on-plants observed a significant increase in } \\
\text { number of blood vessels }\end{array}$ & {$[64]$} \\
\hline$\beta 2 \mathrm{AR}$ antagonist & Coverslip & $\begin{array}{c}\text { Increased number of blood vessel branch points observed } \\
\text { within on-plants }\end{array}$ & [156] \\
\hline Angiogenin & Thermonox discs & $\begin{array}{l}\text { Visibly increased number of blood vessel spoke wheel pattern } \\
\text { seen radiating from on-plants }\end{array}$ & [157] \\
\hline Adenosine & & $\begin{array}{l}\text { Dose dependent increase in vascular density observed in a } \\
\text { region around on-plant }\end{array}$ & [158] \\
\hline $\begin{array}{l}\text { ADP } \\
\text { ATP } \\
\text { Lactic Acid } \\
\text { Malate }\end{array}$ & Elvax Polymer pellet & $\begin{array}{l}\text { Observation of spoke wheel pattern of blood vessels radiating } \\
\text { from on-plants, with a positive result observed in majority of } \\
\text { samples }\end{array}$ & [127] \\
\hline $\begin{array}{l}\text { Exosomes derived from } \\
\text { chronic myeloid } \\
\text { leukaemia cells (K562) }\end{array}$ & Plastic ring & $\begin{array}{l}\text { Treatment with a higher concentration resulted in an increase } \\
\text { in neovasculature }\end{array}$ & [134] \\
\hline 2-deoxy-D-ribose & Plastic ring & $\begin{array}{l}\text { Angiogenic software calculated a significant increase in } \\
\text { number of branchpoints and average vessel length }\end{array}$ & [111] \\
\hline Sclerostin & Gelatin sponge & $\begin{array}{c}\text { Increased number of blood vessels converging towards } \\
\text { on-plants observed }\end{array}$ & [159] \\
\hline Roxarsone & Gelatin sponge & Increased number of neovessels and blood vessel length & [160] \\
\hline Leptin & Gelatin sponge & $\begin{array}{l}\text { Software measured significantly increased blood vessel tube } \\
\text { length and size }\end{array}$ & {$[71]$} \\
\hline Arsenic & Filter disc & $\begin{array}{l}\text { Dose dependent increase in blood vessel number observed, } \\
\text { however higher doses resulted in negative effects }\end{array}$ & [161] \\
\hline Y2O3 nanoparticles & Scaffold & $\begin{array}{l}\text { Improved blood vessel formation, vascular branching and } \\
\text { blood vessel diameter within the area around scaffolds }\end{array}$ & [162] \\
\hline
\end{tabular}

Although the study of pro-angiogenic treatments focus on the amelioration of vascular conditions such as ischaemia, much of the research involving the CAM assay and anti-angiogenic treatments are oncological, through the reduction in vascularisation of a malignant (growing) tumour $[163,164]$. Table 3 summarises the application of anti-angiogenic treatments on the CAM assay, which resulted in a range of negative effects in the development of new blood vessels. The success of these anti-angiogenic substances may prove useful in the development of cancer treatments.

Interestingly, anti-angiogenic treatments are frequently seen in literature involve the use of chemical substances, such as the chemotherapy drug doxorubicin $[129,165]$ as well as thalidomide derivatives [59]. The application of nanoparticles such as gold [60,84], green [166], zinc tungstate [61] and chitosan derived nanoparticles [94] have high efficacy in the inhibition of blood vessel development, with significant reductions in blood vessel number, length and density reported. 
A method of anti-angiogenic activity with proven potential is the inhibition of various angiogenic growth factors via treatment with targeted antibodies. A WHO approved chemotherapy drug, Avastin ${ }^{\circledR}$ (bevacizumab) is used globally in the treatment of several forms of cancer [167]. Bevacizumaub is an anti-VEGF antibody which has shown potent results by reducing blood vessel density in the CAM assay in several studies [3,80], and other anti-VEGF antibodies have elicited similar effects [168,169]. Equally, the use of anti-human placental growth factor (PGF) [170] and anti-laminin [171] antibodies has led to a significant inhibition of angiogenesis and a delay in blood vessel network development respectively.

Table 3. Examples of protein, viral, micro-RNA and pharmacological treatments applied to the CAM which elicited an anti-angiogenic response.

\begin{tabular}{|c|c|c|c|}
\hline Treatment & Delivery Method & Angiogenic Outcome & Ref. \\
\hline $\begin{array}{l}\text { Nicotinamide adenine } \\
\text { dinucleotide (NAD) } \\
\text { Pyruvate } \\
\text { Succinate Fumarate citrate }\end{array}$ & $\begin{array}{l}\text { 10\% EVA copolymer } \\
\text { Pellet }\end{array}$ & No spoke wheel pattern was observed radiating from on-plants & [127] \\
\hline Avastin (Bevacizumab) & \multirow[t]{2}{*}{ Injected } & $\begin{array}{c}\text { Significantly less vascular nodes and branches were quantified within a } \\
\text { defined area }\end{array}$ & [80] \\
\hline EG-VEGF Antibodies & & $\begin{array}{c}\text { No significant differences in vessel density observed, but dilated medium } \\
\text { and large vessels observed }\end{array}$ & {$[168]$} \\
\hline Methyl blue & Microspheres & No spoke wheel pattern was observed radiating from on-plants & [96] \\
\hline Chloroquine \& Doxorubicin & Agarose pellet & $\begin{array}{l}\text { Combination of doxorubicin and chloroquine resulted in strong } \\
\text { anti-angiogenic effect on capillaries near on-plants }\end{array}$ & [129] \\
\hline Avastin (Bevacizumab) & Pipetted & $\begin{array}{c}\text { Significant decrease in percentage of surface area occupied } \\
\text { by microvessels }\end{array}$ & [165] \\
\hline Vitamin C & Pipetted & $\begin{array}{l}\text { The number of primary, secondary, tertiary, and quaternary blood vessels } \\
\text { was counted, with decrease in quaternary blood vessels quantified }\end{array}$ & {$[3]$} \\
\hline MART-10 (Vitamin D analog) & Pipetted & Reduced vessel branch point numbers observed within a defined area & [172] \\
\hline Green nanoparticles & Gelatin sponge & Decrease in vessels length and branch number within a defined area & [166] \\
\hline Rhaponticin & Filter disc & \multirow{2}{*}{$\begin{array}{c}\text { Software determined a significant reduction in total blood vessel length } \\
\text { Reduction in vessel number, branch points, neovascularization and total } \\
\text { length of vessels }\end{array}$} & [173] \\
\hline Thalidomide derivatives & Filter disc & & [59] \\
\hline $\begin{array}{l}\text { High affinity PGF-specific } \\
\text { Nanobody }\end{array}$ & Filter disc & Significant inhibition of angiogenesis within a defined area & {$[170]$} \\
\hline Antithrombin & Filter disc & $\begin{array}{c}\text { Potent antiangiogenic activity in blood vessel tubules, networks and } \\
\text { branching points }\end{array}$ & [174] \\
\hline Zinc tungstate nanoparticles & Filter disc & $\begin{array}{l}\text { A dose dependent reduction in percentage of surface area occupied by } \\
\text { blood vessels was calculated }\end{array}$ & [61] \\
\hline \multirow[t]{2}{*}{ Gold nanoparticles } & Filter disc & $\begin{array}{c}\text { Software determined a dose dependent reduction in blood vessel size, } \\
\text { length and branch points }\end{array}$ & {$[60]$} \\
\hline & Injected & $\begin{array}{c}\text { Software determined a significant reduction in vessel length and number } \\
\text { of junctions and complexes }\end{array}$ & {$[84]$} \\
\hline \multirow{4}{*}{$\begin{array}{c}\text { miR-7 mimics } \\
\text { Sunitinib (receptor tyrosine } \\
\text { kinase inhibitor) } \\
\text { Vasohibin Adenovirus } \\
\text { Chitosan derivatives } \\
\text { nanoparticles }\end{array}$} & Nitrocellulose rings & A reduction in vascular density within a defined area was visible & [175] \\
\hline & Nitrocellulose rings & A reduction in vascular density within a defined area was visible & {$[175]$} \\
\hline & Matrigel & Macroscopic observations saw inhibition of blood vessel growth & [16] \\
\hline & Methylcellulose disc & Reduction in number of blood vessels in contact with on-plants observed & {$[94]$} \\
\hline Anti-VEGF Antibody & Methylcellulose disc & $\begin{array}{l}\text { Visible anti-angiogenic activity observed through } \\
\text { semi-quantitative evaluation }\end{array}$ & [169] \\
\hline Anti-laminin antibody & Methylcellulose disc & Macroscopic observations saw a delay in capillary network development & [171] \\
\hline Anginex & Plastic ring & $\begin{array}{c}\text { Significant decrease in intersections of blood vessels with concentric rings } \\
\text { projected onto images }\end{array}$ & {$[176,177]$} \\
\hline Angiotensinogen & Plastic ring & $\begin{array}{c}\text { First and second order centripetal blood vessels around on-plants were } \\
\text { counted, with inhibition of smaller blood vessels observed } \\
\text { Following FITC injection, blood vessel density, length and number of } \\
\text { branch points were quantified highlighting inhibition of smaller } \\
\text { blood vessels }\end{array}$ & [178] \\
\hline Obtustatin ( $\alpha 1 \beta 1$ inhibitor) & & Decrease in the number of small new vessels growing towards on-plants & [179] \\
\hline
\end{tabular}

The use of the CAM assay for such a variety of both pro-angiogenic and anti-angiogenic factors: drugs, metabolites and biological substances really enforces the efficiency and applicability of the CAM as a screening tool to model the microcirculation and angiogenic effects of various substances.

\subsection{Cell and Gene Modified Cell On-Plants}

In order to ensure successful tumour cell growth, an array of physiological mechanisms such as vessel co-option, intussusceptive microvascular growth, glomeruloid angiogenesis, 
postnatal vasculogenesis, vasculogenic mimicry and most famously the "angiogenic switch" work together to establish a successful and vast angiogenic network. However, the precise details of many of these mechanisms remain elusive [127,180]. When first applied to the chorioallantoic membrane, tumours undergo a $72 \mathrm{~h}$ avascular period before blood vessel infiltration occurs [27].

The use of cell/tumour on-plants in conjunction with the CAM assay has had widespread use. The CAM microenvironment provides all the growth factors, nutrients required for successful cell growth, and the occurrence of the angiogenic switch allows the secretion of Tumour Angiogenic Factors (TAFs) [181] which in turn, induce angiogenesis and allow the penetration of host blood vessels into the applied grafts [182].

Through the injection of cancer cell lines or application of cells with other scaffolds such as Matrigel or collagen encapsulation, or topically through the pipetting or placing of fully formed tumours onto the membrane, the CAM can be used to monitor and investigate the mechanisms of tumour growth, metastasis, and angiogenesis. Based on the current understanding of the angiogenic switch, it is usually expected that following the application of cancer cells or tumour masses onto the CAM, a pro-angiogenic response occurs.

Table 4 outlines examples of un-treated cells, both from cancerous and healthy cell lines, which have been applied to the CAM assay with the aim of observing their angiogenic effect. In the case of most cancer and tumour cell lines, an increase in angiogenic response can be seen, with only some exceptions, such as in the case of SW480 colon carcinoma [151] and Burkitt's Lymphoma cell lines (BL2) [183] which fail to elicit the anticipated increased vascularisation. Interestingly, the application of non-cancerous cells such as skin grafts and human ovarian tissue can also induce a significant angiogenic response, indicating suitability of the CAM in supporting cell survival.

Table 4. Examples of cellular treatments/ tumours applied to CAM which affected angiogenesis.

\begin{tabular}{|c|c|c|c|c|}
\hline Response & Treatment & Delivery Method & Angiogenic Outcome & Ref. \\
\hline \multirow{14}{*}{ 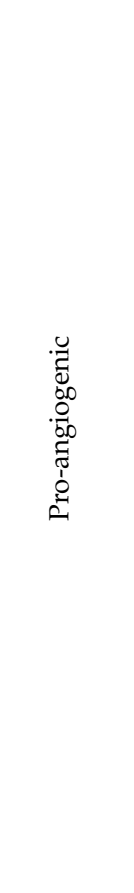 } & $\begin{array}{l}\text { Glioblastoma cancer } \\
\text { stem cells }\end{array}$ & Alginate scaffold & Increased blood vessel number converging towards on-plants & {$[114]$} \\
\hline & $\begin{array}{l}\text { Human umbilical vein } \\
\text { endothelial cells (HUVECs) }\end{array}$ & Cylindrical scaffold & $\begin{array}{l}\text { Increased number of blood vessels and blood vessel } \\
\text { penetration into on-plant }\end{array}$ & [115] \\
\hline & & Cylindrical scaffold & $\begin{array}{c}\text { Increased number of blood vessels and blood vessel } \\
\text { penetration into on-plant }\end{array}$ & [115] \\
\hline & Adipose derived stem cells & Hydrogel & $\begin{array}{c}\text { Significant increase in vessel number, vessel length and } \\
\text { vasculogenic index }\end{array}$ & [74] \\
\hline & & Seeded on a scaffold & $\begin{array}{c}\text { Increased number of blood vessels converging } \\
\text { towards on-plants }\end{array}$ & [108] \\
\hline & & Matrigel & $\begin{array}{c}\text { Following von Willebrand factor staining and semi } \\
\text { quantitative scoring, a significant increase in angiogenesis }\end{array}$ & {$[184]$} \\
\hline & $\begin{array}{l}\text { Burkitt's Lymphoma cell } \\
\text { lines (BL2B95 and BL74) }\end{array}$ & Matrigel & $\begin{array}{c}\text { Following tissue sectioning increase in blood vessel } \\
\text { diameter determined }\end{array}$ & [183] \\
\hline & $\begin{array}{l}\text { Human Liver Cancer } \\
\text { (HepG2) cells }\end{array}$ & Matrigel & $\begin{array}{c}\text { Increased number of blood vessels converging } \\
\text { towards on-plants }\end{array}$ & [86] \\
\hline & $\begin{array}{l}\text { Prostate Cancer Cells } \\
(\mathrm{LNCaP})\end{array}$ & Matrigel & $\begin{array}{l}\text { A change in blood vessel number within a defined } \\
\text { area observed }\end{array}$ & [185] \\
\hline & Colon carcinoma (SW620) & Matrigel & Increase in angiogenic index was observed & [54] \\
\hline & $\begin{array}{l}\text { Neuroblastoma } \\
\text { (NB15/FOXO3 cells) }\end{array}$ & Matrigel & $\begin{array}{l}\text { Following desmin staining, increased micro-vessel formation } \\
\text { was observed }\end{array}$ & [56] \\
\hline & $\begin{array}{l}\text { Glioblastoma (U87 MG) } \\
\text { Cell lines }\end{array}$ & Matrigel & $\begin{array}{l}\text { Increased observation of spoke wheel pattern of blood vessels } \\
\text { radiating from on-plants }\end{array}$ & [55] \\
\hline & $\begin{array}{c}\text { Human Cardiopoietic } \\
\text { Stem Cells }\end{array}$ & Scaffold & Blood vessel density within a defined area was increased & [186] \\
\hline & $\begin{array}{l}\text { Multiple myeloma } \\
\text { plasma cells }\end{array}$ & Gelatin sponge & Induction of an increased vasculogenic index was calculated & [66] \\
\hline
\end{tabular}


Table 4. Cont.

\begin{tabular}{|c|c|c|c|c|}
\hline Response & Treatment & Delivery Method & Angiogenic Outcome & Ref. \\
\hline \multirow{13}{*}{ 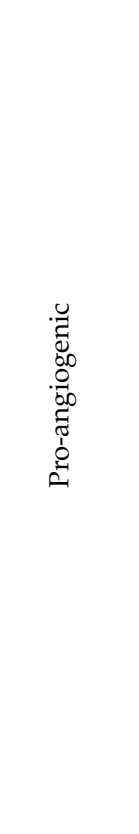 } & Mouse Melanoma (B-16) & Plastic ring & $\begin{array}{c}\text { Development of visible spoke wheel pattern of blood vessels } \\
\text { converging towards on-plants }\end{array}$ & [187] \\
\hline & Human Melanoma (C8161) & Plastic ring & \multirow{3}{*}{$\begin{array}{c}\text { Significant increase in area occupied by endothelial cells } \\
\text { observed within a defined area }\end{array}$} & \multirow{3}{*}{ [75] } \\
\hline & \multirow{2}{*}{$\begin{array}{l}\text { Human Prostate Cancer } \\
\text { (PC3) }\end{array}$} & Hydrogel & & \\
\hline & & Plastic ring & & \\
\hline & Skin graft & Plastic ring & $\begin{array}{l}\text { Photobiomodulation along with cell application resulted in } \\
\text { increased number of vascular junctions within a defined area }\end{array}$ & [104] \\
\hline & Human Ovarian Tissue & Plastic ring & $\begin{array}{c}\text { Visual estimation of area occupied by blood vessels compared } \\
\text { to total surface area resulted increased angiogenesis and } \\
\text { neovascularisation }\end{array}$ & [188] \\
\hline & Melanoma Tumour Tissue & Tumour & $\begin{array}{c}\text { Spoke wheel pattern of capillaries converging towards } \\
\text { on-plants observed }\end{array}$ & [189] \\
\hline & $\begin{array}{l}\text { Recurrent respiratory } \\
\text { papilloma tissue (RRP) }\end{array}$ & Tumour & $\begin{array}{l}\text { Increase in blood vessel number within a defined } \\
\text { area observed }\end{array}$ & [125] \\
\hline & $\begin{array}{l}\text { Hepatocellular Carcinoma } \\
\text { Tumour tissue }\end{array}$ & Tumour & Increased micro vessel density within a defined area observed & [190] \\
\hline & $\begin{array}{l}\text { Human Malignant Ovarian } \\
\text { tumours }\end{array}$ & Tumour & $\begin{array}{l}\text { Increase in the pattern, density, and size of the CAM blood } \\
\text { vessels near the tumour implants visible }\end{array}$ & [191] \\
\hline & $\begin{array}{c}\text { Adenocarcinoma } \\
\text { Tumour Tissue }\end{array}$ & Tumour & $\begin{array}{l}\text { Increase in the pattern, density, and size of the CAM blood } \\
\text { vessels near the tumour implants visible }\end{array}$ & [191] \\
\hline & Glioma cells (C6) & Injected & $\begin{array}{c}\text { Macroscopic observations indicated tumours became } \\
\text { vascularised by CAM blood vessels }\end{array}$ & [78] \\
\hline & $\begin{array}{l}\text { Pancreatic carcinoma } \\
\qquad(10 \mathrm{AS})\end{array}$ & Injectí & $\begin{array}{l}\text { Macroscopic observations indicated tumours became } \\
\text { vascularised by CAM blood vessels }\end{array}$ & [78] \\
\hline$\cdot \breve{u}$ & Colon carcinoma (SW480) & Collagen & No Induction of angiogenesis or increased angiogenic index & {$[54]$} \\
\hline 畩 & $\begin{array}{l}\text { Burkitt's Lymphoma cell } \\
\text { lines (BL2) }\end{array}$ & Matrigel & $\begin{array}{l}\text { Following tissue sectioning reduced blood vessel } \\
\text { diameter observed }\end{array}$ & {$[183]$} \\
\hline
\end{tabular}

Angiogenesis is a hallmark of cancer [182], therefore from an oncology aspect, the angiogenic activity of cells is often an area of particular interest, and a potential target area in the development of possible therapeutics or drugs which could hinder this effect. Consequently, the use of the CAM assay as an efficient biological screening tool on the focus of cell induced angiogenesis could prove paramount. Following genetic or other forms of modifications of cells, the changes in cell behaviour or the surrounding media (conditioned media) taken from cells can be an exciting area of focus. Table 5 outlines examples of various cell lines which have been treated or genetically modified to elicit a different angiogenic behaviour compared to their un-modified counterparts.

Table 5. Examples of treated and gene modified cells or conditioned media (CM) applied to CAM assay.

\begin{tabular}{|c|c|c|c|c|c|}
\hline & Gene Modification & Cell Type & Delivery Method & Angiogenic Response & Ref. \\
\hline \multirow{6}{*}{ 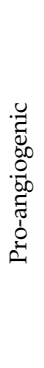 } & FGF-1 expression plasmid & Bovine Endothelial Cells & Gelatin sponge & $\begin{array}{l}\text { Following tissue sectioning, and staining for von Willebrand } \\
\text { Factor, a twofold increase in capillary number was quantified }\end{array}$ & [135] \\
\hline & LV miR-205 inhibition & $\begin{array}{l}\text { Endothelial } \\
\text { colony-forming cell CM }\end{array}$ & Not mentioned & $\begin{array}{c}\text { Software quantified significant increase in blood vessel } \\
\text { density within a defined area }\end{array}$ & [192] \\
\hline & Sphingosine-1-phosphate treated & $\begin{array}{l}\text { Osteoblast cell } \\
\text { (MG-63) CM }\end{array}$ & & $\begin{array}{c}\text { Increase in blood vessel number within a defined area } \\
\text { was quantified }\end{array}$ & [193] \\
\hline & miR-338-3p inhibition plasmid & $\begin{array}{l}\text { Hepatocellular carcinoma } \\
\text { (HCC) CM }\end{array}$ & Filter disc & $\begin{array}{l}\text { Visual inspection of second and third order blood vessels } \\
\text { inferred increased blood vessel formation }\end{array}$ & [194] \\
\hline & AGO2 expression plasmid & Myeloma cell CM & & $\begin{array}{c}\text { Significant increase in on-plant infiltrating blood } \\
\text { vessels observed }\end{array}$ & [195] \\
\hline & $\begin{array}{c}\text { IFN- } \gamma \text { treated } \\
\text { TNF- } \alpha \text { treated } \\
\text { IFN- } \gamma \text { and TNF- } \alpha \text { treated }\end{array}$ & $\begin{array}{l}\text { Mesenchymal stem } \\
\text { cell CM }\end{array}$ & Pipetted & $\begin{array}{l}\text { A significant increase in number of small blood vessels } \\
\text { (diameter less than } 1 \mathrm{~mm} \text { ) } \\
\text { A significant increase in both small and large blood vessels }\end{array}$ & [196] \\
\hline
\end{tabular}


Table 5. Cont.

\begin{tabular}{|c|c|c|c|c|c|}
\hline & Gene Modification & Cell Type & Delivery Method & Angiogenic Response & Ref. \\
\hline \multirow{15}{*}{ 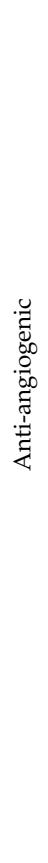 } & AAV-Timp1- transduced & $\begin{array}{l}\text { Chinese hamster } \\
\text { ovary cells }\end{array}$ & Gelatin sponge & $\begin{array}{l}\text { No spoke wheel pattern of blood vessels radiating } \\
\text { from on-plants }\end{array}$ & [197] \\
\hline & $\begin{array}{l}\text { LV mediated Angiopoietin-2 } \\
\text { shRNA }\end{array}$ & Pancreatic carcinoma cells & Pipetted & Decrease in number of blood vessel branch points & [198] \\
\hline & $\begin{array}{l}\text { Connective tissue growth factor } \\
\text { (CTGF)-shRNA }\end{array}$ & OASF cell CM & Pipetted & Significant reduction in blood vessel count & [199] \\
\hline & Endostatin expression plasmid & COS-1 cell CM & Pipetted & Significant reduction in blood vessel branch points & [200] \\
\hline & LV VEGF shRNA & $\begin{array}{l}\text { Hypertriploid renal cell } \\
\text { carcinoma CM }\end{array}$ & Pipetted & $\begin{array}{c}\text { Significant decrease in blood vessel counts and total blood } \\
\text { vessel length }\end{array}$ & [201] \\
\hline & CCL5-shRNA & $\begin{array}{l}\text { Chondrosarcoma cells } \\
\text { (JJ012) }\end{array}$ & Matrigel & Significant decrease in blood vessel branches & [202] \\
\hline & Sema3C transfected & $\begin{array}{l}\text { Glioblastoma cell line } \\
\text { (U87 MG) }\end{array}$ & Collagen & $\begin{array}{c}\text { Diminished observation of a spoke wheel pattern of blood } \\
\text { vessels radiating from on-plants }\end{array}$ & [55] \\
\hline & AGO2-shRNA & Myeloma cell CM & Filter disc & $\begin{array}{c}\text { Lower blood vessel densities infiltrating the } \\
\text { on-plants observed }\end{array}$ & [195] \\
\hline & $\begin{array}{c}\text { Vascular endothelial cell growth } \\
\text { inhibitor (VEGI) expression } \\
\text { plasmid }\end{array}$ & HeLa cell CM & Filter disc & Significant inhibition of neovascularization & [203] \\
\hline & $\begin{array}{c}\text { Novel immunotoxin } \\
\text { (VEGF165-PE38) expression } \\
\text { plasmid }\end{array}$ & HEK293 cell CM & Not mentioned & Inhibition in growth of capillary-like structures & [204] \\
\hline & LV miR-205 OE & $\begin{array}{l}\text { Endothelial } \\
\text { colony-forming cell CM }\end{array}$ & & Visual inspection saw reduced blood vessel formation & [192] \\
\hline & miR-181a-5p expression plasmid & $\begin{array}{l}\text { Fibrosarcoma (HT1080) } \\
\text { cell CM }\end{array}$ & Gelatin sponge & Impairment of new blood vessel formation observed & [205] \\
\hline & $\begin{array}{l}\text { Nuclear Factor-Erythroid } 2 \\
\text { (NRF2) shRNA }\end{array}$ & $\begin{array}{l}\text { Human colon cancer cell } \\
\text { CM }\end{array}$ & Matrigel & $\begin{array}{l}\text { Significant reduction in blood vessel branch points in circular } \\
\text { region around on-plants }\end{array}$ & [206] \\
\hline & P53 Isoform $(\Delta 133 p 53)$ deletion & $\begin{array}{l}\text { Human Glioblastoma } \\
\text { (U87) cell CM }\end{array}$ & Silicon ring & $\begin{array}{c}\text { Following tissue sectioning and staining, reduced blood } \\
\text { vessels quantified }\end{array}$ & [207] \\
\hline & LV miR-542-5p & $\begin{array}{l}\text { Non-small cell lung } \\
\text { cancer CM }\end{array}$ & Silicon ring & Significant reduction in percentage vascular density & [109] \\
\hline
\end{tabular}

Key: CM: conditioned media; LV: Lentiviral; miR: microRNA; OE: Overexpression; shRNA: short hairpin RNA.

Once cells are modified to inhibit their pro-angiogenic ability, the CAM assay can be employed as a confirmation tool in order to highlight the efficacy and mechanism of action of the modification. Alternatively, cells can be altered to increase their angiogenic potential, through inhibition or overexpression of certain genes. The efficacy of these cells at inducing a pro-angiogenic response can be measured using the CAM assay [194,196,208].

It must also be noted that in the case of certain cell lines, the pro-angiogenic modification to cells may elicit benefits, especially in areas such as cell therapy, where overexpression of vascular factors could provide a treatment option in therapeutic angiogenesis, to improve the vascularisation of previously ischaemic tissue [135].

Methods of adjusting the angiogenic potential of cells can vary from pre-treating cells with drugs or inflammatory factors such as sphingosine-1-phosphate [193], interferon or tumour necrosis factor [196], to more complex methods of genetically modifying the angiogenic behaviour of a cell.

Studies have used gene expression plasmids to stably transfect cell lines, establishing cells which overexpress various angiogenic or anti-angiogenic factors. The gene modified cells, or the conditioned media of these cells is applied onto the CAM assay respectively.

Examples of angiogenic expression plasmids transfected into cells include FGF plasmid transfection into bovine endothelial cells [135] and argonaute-2 transfected into myeloma cells [195], both of which lead to significant increases in capillary and infiltrating blood vessel numbers following cell-mediated delivery onto the CAM assay. Conversely, the cellmediated inhibition of blood vessel formation can be seen with transfected anti-angiogenic expression plasmids such as vascular endothelial cell growth inhibitor (VEGI) [203], endostatin [200], or the novel immunotoxin (pVEGF165PE38-IRES2EGFP) [204].

In recent years, gene modifying agents including miRNAs (miRs) have become very popular therapeutic targets. Overexpression or inhibition of various miRs can impact on angiogenic potential of cells through a variety of means. Zhang et al. used an expression plasmid to inhibit the anti-angiogenic function of miR-338 in hepatocellular carcinoma, leading to a significant increase in small blood vessel formation in the CAM assay [194]. Conversely, Li et al. overexpressed miR-181a-5p in fibrosarcoma (HT1080) cells leading to a reduction in CAM blood vessel formation [205]. 
Interestingly, Jiang et al. focused their research on how the overexpression or inhibition of miR-181a-5p could both attenuate and increase the angiogenic potential of endothelial colony-forming cells (ECFCs) in conjunction with the CAM assay. In this study, lentiviral vector inhibition of miRNA-205 in ECFCs led to an increase in blood vessel density. However overexpression of miRNA-205 resulted in visibly reduced blood vessel formation [192].

Short Hairpin RNAs (shRNAs) are small, manufactured RNA molecules with a sharp hairpin turn used to silence or knockdown gene expression through RNA interference (RNAi) [209]. ShRNAs have been used to inhibit several angiogenic genes and miRNAs in cells applied to the CAM assay, with delivery seen both as direct shRNA delivery, or lentiviral mediated delivery into cells. ShRNA inhibition of potent pro-angiogenic genes is seen throughout the literature, through the knockdown of VEGF [201], connective tissue growth factor [199] and angiopoietin-2 [198] resulting in significant reductions in angiogenic effects in the CAM assay, as outlined in Table 5.

The study of cell application onto the CAM assay monitoring angiogenic response is one with much potential. The applicability and ease of use of the CAM assay is proven by the ease at which grafts can be applied and their survival supported. Use of the CAM assay can provide a screening tool for the inherent angiogenic nature of the cells and the effect of gene/chemical modifications on this inherent ability. However, this is an area which still needs much further exploration.

\section{CAM Analyses}

Considering the success of on-plant treatments using the CAM assay, emphasis has focused on the method of analysis chosen to quantify an angiogenic effect. Assessment of the angiogenesis occurring due to stimuli can be carried out by a variety of different methods. Some studies choose to use arbitrary quantification methods, such as visual or macroscopic evaluation or observation of an angiogenic effect between experimental groups [16,121,147] and define the results simply as positive or negative [210]. While other studies indicate a positive or negative angiogenic effect due to the presence or absence of a "spoke-wheel pattern" of blood vessels approaching an on-plant [55,127]. In the majority of studies such as these, assessments are carried out in a blinded manner in order to prevent bias affecting the results $[64,90,104]$. The use of adequate positive, negative, and internal controls for comparison using the CAM assay is essential. Generally, neutral phosphate buffered saline (PBS) treated vehicles or scaffolds are used as an internal control, while known angiogenic agonists (such as VEGF) and antagonists (bevacizumab) can be used as a positive and negative controls respectively [80].

Some studies have chosen to compare treated areas of the CAM with non-treated areas [190], others compare the angiogenic effect of an internal control against the treatment; an internal control usually is found in the form of an empty scaffold or a scaffold treated with an angiogenic neutral substance, such as PBS or the solvent used for the delivery of the treatment. Comparison of a treated area to an internal control is preferable and more accurate as it results in less variation between test and control, while also considering the angiogenic response that the vehicle alone can induce.

As individual scoring or assessment methods of CAM treatments can result in conscious or unconscious bias in either direction, a multiprong approach of using different imaging, scoring and assessment techniques is recommended, with the cross-referencing and correlation of results obtained essential to create an overall profile of the angiogenic effects.

\subsection{Sectioning and Staining Techniques}

Following the sacrificing of the chick embryos, the CAM tissue can be fixed using paraformaldehyde or other fixative solutions, excised from the embryo, embedded in paraffin and then undergo sectioning or ultra-sectioning in preparation for histochemical staining for various indicators of angiogenesis such as endothelial and smooth muscle cell markers [211]. Blood proteins such as haemoglobin [212], von Willebrand factor [184,213] or 
the filament protein desmin [56] have been studied as a measure of blood vessel density and consequently, the vascularisation present [183]. Histological staining of endothelial cells with biotin or fluorescent tagged lectins has also been successfully achieved to visualise vascularisation present in CAM tissue [207,214], while immunohistochemical staining of endothelial cells using anti-CD31 antibodies has also been employed $[97,215,216]$.

While the quantity of newly formed blood vessels is often the focus of many studies, the quality should also be considered. An issue with some pro-angiogenic factors dependent on dosage levels can be the development of aberrant and leaky blood vessels, inferior to those formed from natural angiogenesis. To investigate this, Pink et al. (2012), developed a modified version of a Miles Assay, a commonly used technique which measures vascular leakage, allowing both the quantity and quality of angiogenesis to be assessed [110,124,217]. In this study, the leakiness of the newly formed blood vessels was quantified by spectrophotometrically measuring the amount of leaked Evan's blue dye following a single bolus injection. Alternatively, the injection of fluorescent dyes such as various FITC-dextrans of different molecular weights [218-220] or FITC and rhodamine conjugated lectins into CAM tissue can prove useful for measurements of vascular leakiness [211]. In this process, fluorescent dyes are injected into the vitelline vein (Figure 4), given time for the dye to circulate, and then observed under fluorescent light, also highlighting smaller capillaries which would otherwise be unquantifiable.

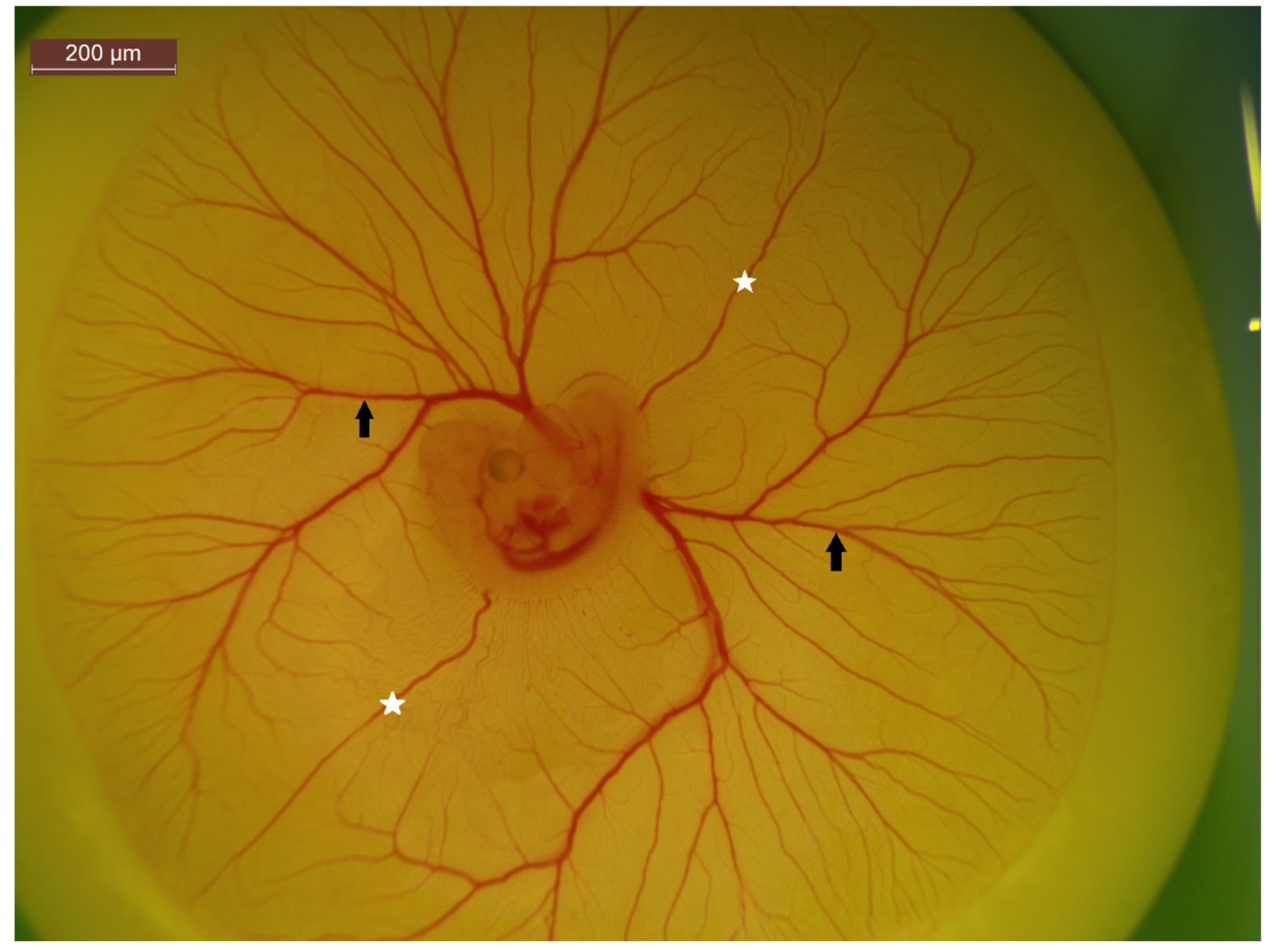

Figure 4. A 5-day-old chick embryo highlight CAM vasculature. The white stars represent anterior and posterior vitelline veins, while the black arrows indicate vitelline arteries and veins. The nonbranching nature of the vitelline veins make it an ideal location for injections.

\subsection{Image Quantification Techniques}

Automated, semi-automated and manual serological methods can be used to quantify neovascularisation and angiogenesis. For automated methods, many software packages exist which can be adapted to identify tubules, vessel branch points and network junctions. Such software packages include: Angiotool [221], AngioQuant [60,73,137], Wimasis [87,101], HetCAM [222], Photoshop CS4 [223] and Synedra view [224]. Image analysis software such as Image J can be used for both manual and semi-automated quantification methods. In a semi-automated manner, pixel intensity, or percentage of binary images containing 
blood vessels can be used to measure blood vessel density [141,225,226]. While manually counting tools can be used to quantify the number of blood vessels, junctions or branching points visible within a defined area $[80,227,228]$.

Various parameters can be chosen to assess an angiogenic effect; basic approaches can involve simply counting the blood vessels or quantifying blood vessel length within a circle or square area around an on-plant [215] or converging towards it. More complex methods can involve the scoring of blood vessels based on a centripetal ordering method (Figure 5A), where a blood vessel is order-1, continuous with the capillary network, or order-2, formed from the convergence of two order- 1 vessels [178,229]. An alternative method is where an array of concentric circles is projected onto a CAM image with a vascular score then assigned based on the intersection of these circles with blood vessels, without discrimination between arterial or venous vessels (Figure 5B) $[37,64,176,177,230]$.

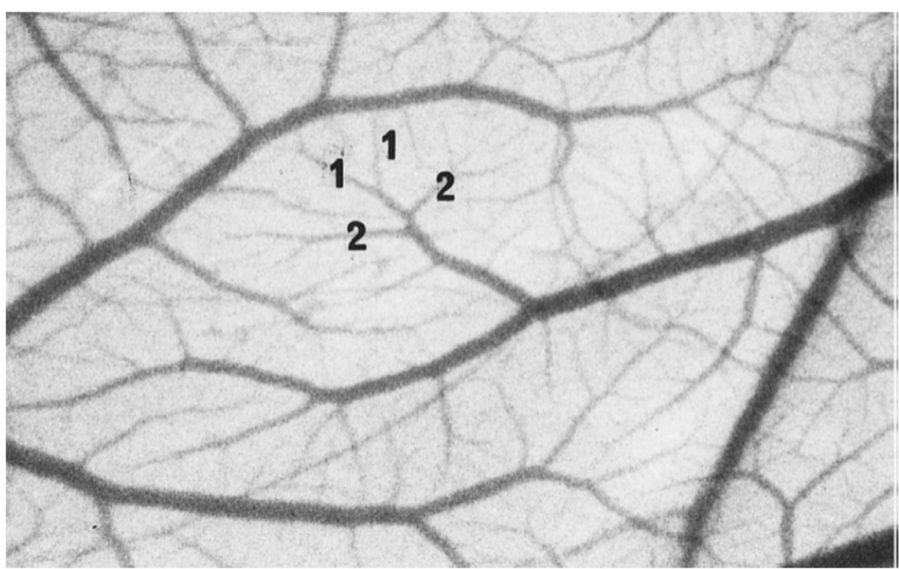

(A)

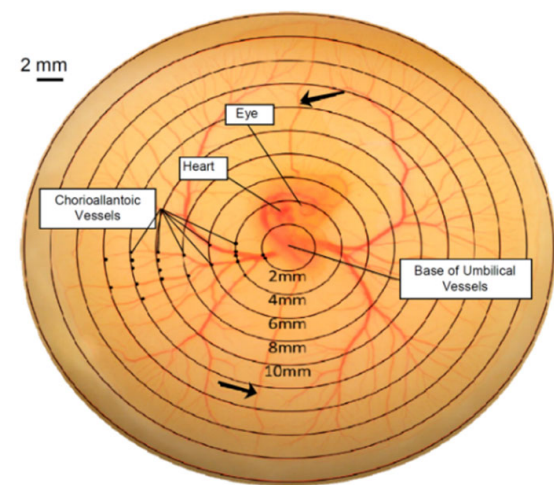

(B)

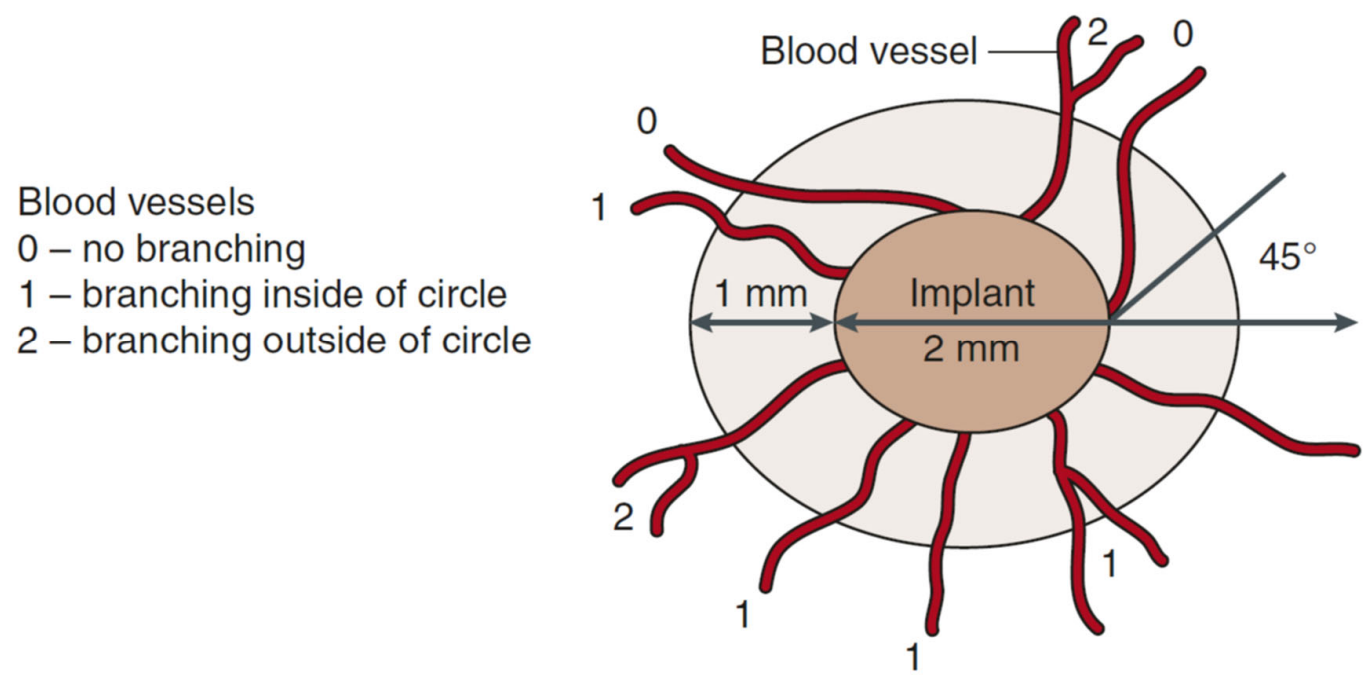

(C)

Figure 5. Examples of CAM analysis techniques to quantify angiogenic score following treatment. In the case of each of these methods, each blood vessel which fits specific criteria is given a score, with the accumulative score then determined for each on-plant/treatment. (A) Centripetal ordering method of angiogenic scoring, where vessels are assigned a score based on the order of their branching, with higher order vessels getting a higher score as described in DeFouw et al. [231]. (B) A range of concentric circles projected onto an image of a CAM where the total vascular index quantified based on the intersection of blood vessels with each of the circle, as described in Burggren et al. [230]. (C) Evaluation of a angiogenic response by scoring vessel branching as described by Ribatti et al. [32], this method involves the assigning of an angiogenic score ranging from 0-2 based on branching and angle of approach. 
Ribatti et al., 2007 describes a method where an angiogenic score is assigned to a blood vessel entering an on-plant at a specific angle (Figure 5C) [32,37]. Although, this is a widely used scoring method, issues can arise. Without discrimination of blood flow direction in vessels, determination whether a blood vessel is growing towards or away from an on-plant cannot be fully discerned. Another consideration is that due to the vague nature of branching, scoring and angles as described in this method, individual interpretations and differences in scores can result between analysts studying the same images, leading to erroneous experimental outcomes.

Many image techniques and scoring systems fail to fully explore the changes in microcirculation in response to a treatment. In many studies, the macroscopic observations of larger blood vessels are the main focus, with little attention drawn towards the minute microvessels and capillaries present. This seems to be a major oversight when the study and investigation of pro angiogenic or anti-angiogenic treatments are considered, where even the smallest modifications to vascularisation should be scrutinized.

\subsection{Vascular Casting}

A negative aspect of image quantification and study is that only sporadic random areas of microvascularisation in the CAM are usually observed. However, the development of a three-dimensional microvascular corrosion casting (vascular casting) method could provide an overall thorough study of the vascular changes occurring in the CAM [232]. Corrosion casting is an anatomical method where a solid faithful replica of a biological sample is produced from a hollow anatomical structure or space. In this process, following perfusion to flush out the area, a flexible substance (such as rubber, resin or polyurethane) in liquid form is injected into the space, allowed to solidify and then the surrounding tissue is removed by enzymatic or chemical degradation [233].

This method is particularly useful in the study of vasculature in conjunction with angiogenic assays, where vascularisation and blood vessels distribution and organisation can be measured [234]. Following the production of a vascular cast, examination of the normal or abnormal blood vessel network can be carried out by scanning electron microscopy $(\mathrm{SEM})$, micro computed tomographic $(\mu \mathrm{CT})$ imaging, or synchrotron radiation-based micro computed tomographic (SR $\mu \mathrm{CT})$ imaging [235].

In the case of the CAM assay, the chorioallantoic membrane is carefully incised at the central vein, flushed with a sodium chloride $(\mathrm{NaCl})$ and heparin solution to clear the blood, and then perfused with a cast material such as Polyurethane, Clear Flex 95 or Mercox ${ }^{\circledR}$ [236]. Following this, the cast substance is given time to polymerise and then the CAM tissue is dissolved over several days or weeks in 5-20\% potassium hydroxide $(\mathrm{KOH})$ or $20 \%$ sodium hydroxide $(\mathrm{NaOH})$ followed by rinsing in distilled water or formic acid [234]. Following cast formation, a sputter-coating of gold, silver, platinum, or chromium from $10 \mathrm{~nm}$ to $25 \mathrm{~nm}$ in thickness may also be required in conjunction with scanning electron microscopy in order to improve image quality $[48,235,237]$.

This method of CAM examination has proven advantageous as it allows for a threedimensional representation of the vascular network, allowing visualisation of branch points, and indicators of sprouting and intussusceptive angiogenesis $[8,48,146]$, often also being used as a validation method when investigating the efficacy of different imaging techniques [238,239]. As a detailed representation of the CAM vasculature is produced, with the use of the correct casting material, orientation, distribution and frequency of endothelial cells and aberrations in blood vessels can be resolved [234].

\subsection{Live Blood-Flow Observation}

Many of the approaches mentioned previously involve the use of non-viable excised and fixed dead tissue, with observation of morphological characteristics. Several approaches have been developed for the observation of real-time in vivo blood flow and circulation in the CAM. The observation of microcirculation in real-time is advantageous as it can monitor for vascular leaks, variations in vessel quality and density, while also 
indicating the delivery and efficacy of a treatment. Real-time blood flow can be observed by a wide array of means, including the use of nanoparticles or fluorescently labelled erythrocytes injected into the CAM, or the use of fluorescent dyes or dextrans which are then viewed using intra-vital fluorescent microscopy (IVFM) [29] (Video S1), or alternatively the use of photodynamic therapy (PDT) $[85,191]$.

\subsection{Molecular Analysis}

Although it is useful to observe a visual effect following treatment, molecular analysis of the CAM assay can also prove useful in the understanding of the biochemical mechanisms behind the changes in vascularisation which are observed. To this end, molecular approaches such as quantitative PCR, in situ hybridisation (mRNA), whole mount immunostaining and immunoblotting (protein) can be employed [39].

Quantitative PCR is an essential form of molecular analysis which can prove useful in measurement of changes in gene expression in CAM tissue following various treatments, cells or tumour applications. In some cases, measurement of precise areas around the treatment location are required, therefore laser dissection of CAM tissue can be utilised [240]. Trizol or mRNA isolation kits are often used to extract total RNA from dissected CAM tissue, with qPCR or semi-quantitative PCR then carried out to measure expression of various genes, including those related to angiogenic pathways. In the case of semi-quantitative PCR, following gene amplification, the PCR products are electrophoresed on a polyacrylamide or agarose gel with the band intensities then measured [8,71,214,241]. The use of a suitable chicken specific primer for housekeeping gene expression is paramount in qPCR to ensure accurate, quantifiable results to compare with genes of interest. It also can be used to measure the quality and integrity of the RNA isolated, with $\beta$-actin and GAPDH most commonly used in the case of CAM tissue [60,71,134].

In the use of the CAM assay as a model of tumour growth and metastasis, the quantity of human cells present within tissues extracted from chick embryos can be determined by qPCR amplification of the Alu repeat sequences repeats (Alu-qPCR) [54,242]. Alu elements are non-autonomous retrotransposons, which are uniquely present in a primate genome and absent in chicken DNA. Alu PCR can be used a DNA fingerprinting technique to calculate the quantity of human DNA present in CAM tissue [243].

This method has been used in several studies to examine the engraftment and migration of cancer cells from a tumour placed on the CAM surface through the CAM and even into the chick embryo itself, travelling via the vast vascular network present. In summary, to quantify human tumour cell intravasation into the chick CAM, semi-quantitative real time PCR is carried out to amplify Alu sequences in order to calculate the amount of human DNA present in each CAM sample. A standard curve generated by serial dilution of human tumour cells is then used to quantify the actual number of tumour cells present in each CAM sample $[17,244,245]$. In addition to this analysis, quantification of chick DNA present should be carried out through amplification of a chick house-keeping gene, such as the chick GAPDH genomic DNA sequence [246]. Horst et al. optimised this process, establishing a TaqMan ${ }^{\circledR}$ based quantification method to measure human Alu sequence amplification in genomic DNA from CAM tissue showing improved success compared to the SYBR ${ }^{\circledR}$ Green methods used previously [247].

While study of gene expression can provide insights into the changes occurring in CAM tissue, several studies have instead chosen to quantify the protein expression present by means of Western blotting (immunoblotting). In this process, CAM tissue is crushed or minced, lysed with a suitable lysis buffer such as radioimmunoprecipitation assay (RIPA) buffer. Then the samples are denatured in a suitable loading buffer, such as Laemmli buffer and electrophoresed on an SDS Polyacrylamide gel (SDS-PAGE). Following this, lysates are then transferred to a membrane and probed using various primary antibodies $[39,248]$. In immunoblotting, use of a suitable protein loading control is imperative, chicken specific $\alpha$-tubulin and $\beta$-actin antibodies have been used in several CAM tissue immunoblots [71,151,249]. 
Purification of protein extracted from CAM tissue prior to denaturing and SDS-PAGE may be necessary to ensure success. After protein isolation from CAM tissue, immunoprecipitation of samples can be carried out by various means to enrich for the specific protein of interest. Ribatti et al. used Heparin-Sepharose columns to purify protein extracted from CAM tissue prior to immunoblotting and probing for bFGF [250]. Similarly, protein A-Sepharose beads bound with suitable antibodies have also been used with much success [58,251].

Some studies use a two-pronged approach for molecular analysis, using both methods to measure gene, and protein expression. Mangieri et al. used RT-PCR, Western blotting and a visual scoring method to assess increased angiogenesis in the CAM following multiple myeloma endothelial cell treatments. In this investigation, the mRNA expression level of various angiogenic genes, including endostatin, in CAM tissue was measured by qPCR, while Western blotting examined for the altered protein expression of endostatin [249]. Using both methods allowed for correlation of results obtained, where both reduced gene expression and protein secretion of endostatin was observed.

Molecular analysis used in conjunction with other methods of analysis can be extremely useful in investigating the overall effects certain treatments or cell applications can have on the growth and development of the CAM membrane. Immunoblotting can investigate protein secretions, while qPCR examines gene up-regulation or down-regulation. Alternative methods of molecular analysis can include transcriptome analysis of cRNA isolated from CAM tissue following treatments [97]. Gelatin Zymography is another molecular process, where samples are electrophoresed on a polyacrylamide gel containing gelatin, then incubated in collagenase buffer with gelatinolytic activity and finally visualised using $0.5 \%$ Coomassie blue [252]. The aforementioned methods are useful in identifying the signalling pathways which result from the application of pro-angiogenic or anti-angiogenic factors.

\section{Advantages and Limitations of the CAM to Study Microcirculation}

Generally, it can be seen that the CAM assay offers many advantages for quantifying angiogenesis over other in vitro and other in vivo methods. Predominantly, the low cost, accessibility, rapid growth and enclosed mechanism of survival make it a clear choice to be used as a research tool $[28,33]$. The CAM assay is flexible, with a wide variety of treatment methods and delivery options available, with the resulting changes in vasculature assessed by a variety of means. The outputs of a CAM assay can be seen in real time, with the general growth period of the angiogenic window restricted to around developmental day 12. As with all animal models, the CAM has some limitations. Many molecular assessment methods require the acquisition of less widely available chick-specific reagents, antibodies, and probes, as well as specialised equipment and incubators for the experimental process. The developing chick does not have a functioning immune system until development day 18. Therefore, the application of test treatments does not illicit an immune response. However, this can also lead to negative repercussions, the absence of an immune response in the chick can be advantageous, however this lack of protection can hinder the survivability of the chick following invasive techniques such as cultivation (in ovo versus ex ovo). This along with the individual differences between eggs, leads to the requirement of larger sample sizes (n number) of chicks in order to obtain statistical power.

In CAM image analysis, there is large flexibility in the variety of methods for assessment of angiogenic responses. However, this can be misleading as there can be a lack of clarity between different studies as to what determines a significant effect of change in vascularisation. Flexible forms of assessment and arbitrary quantification may not consider natural morphological changes due to the growing embryo alone rather than the treatment applied. 


\section{Concluding Remarks}

In the scientific study of microcirculation and angiogenesis, an in vivo approach is very advantageous over in vitro methods. The CAM assay has proven itself to be an invaluable tool in this regard. Presently, the CAM assay is used as a research method in the fields of biology, bioengineering, and chemistry for a wide variety of applications. Although individual laboratory methods, treatment techniques and assessment methods hinder the standardisation of this assay, it does have great potential to be used as an invaluable preliminary and/or complimentary screening tool before examination in higher order animals or a more specific in vivo experimental approach. Overall, the CAM assay is an excellent tool for research, with a low cost, high flexibility, accessibility, with a clear experimental approach. It should be considered greatly for vascular studies before any experimentation using rodents or larger level pre-clinical animal models are commenced. In this regard, the CAM is very much supporting a reduced reliance on pure animal research and following the 3Rs (replacement, reduction, refinement) approach to animal research.

Supplementary Materials: The following are available online at https:/ /www.mdpi.com/article/10 $.3390 / \mathrm{ijms} 23010452 / \mathrm{s} 1$.

Author Contributions: Conceptualization, D.C.K., A.M.W. and K.J.A.M.; literature search, D.C.K.; writing-original draft preparation, D.C.K.; writing-review and editing, D.C.K., A.M.W. and K.J.A.M.; Images and video production, B.C. and D.C.K.; supervision, K.J.A.M.; project administration, K.J.A.M. and D.C.K.; funding acquisition, K.J.A.M., D.C.K. and A.M.W. All authors have read and agreed to the published version of the manuscript.

Funding: This research was funded by the Irish Research Council and the College of Medicine Nursing \& Health Sciences at NUIG. D.K received a Government of Ireland Postgraduate scholarship from the Irish Research Council (GOIPG/2018/2622).

Institutional Review Board Statement: Not applicable.

Informed Consent Statement: Not applicable.

Data Availability Statement: Not applicable.

Conflicts of Interest: The authors declare no conflict of interest.

\section{References}

1. Giaccia, A.J.; Simon, M.C.; Johnson, R. The biology of hypoxia: The role of oxygen sensing in development, normal function, and disease. Genes Dev. 2004, 18, 2183-2194. [CrossRef]

2. Grace, P. Ischaemia-reperfusion injury. Br. J. Surg. 1994, 81, 637-647. [CrossRef]

3. AS, M.N.; Deshpande, R.; Kale, V.P.; Bhonde, R.R.; Datar, S.P. Establishment of an in ovo chick embryo yolk sac membrane (YSM) assay for pilot screening of potential angiogenic and anti-angiogenic agents. Cell Biol. Int. 2018, 42, 1474-1483. [CrossRef] [PubMed]

4. Ribatti, D.; Crivellato, E. “Sprouting angiogenesis", a reappraisal. Dev. Biol. 2012, 372, 157-165. [CrossRef] [PubMed]

5. Ausprunk, D.; Knighton, D.; Folkman, J. Vascularization of normal and neoplastic tissues grafted to the chick chorioallantois. Role of host and preexisting graft blood vessels. Am. J. Pathol. 1975, 79, 597. [PubMed]

6. Djonov, V.; Schmid, M.; Tschanz, S.A.; Burri, P.H. Intussusceptive angiogenesis: Its role in embryonic vascular network formation. Circ. Res. 2000, 86, 286-292. [CrossRef]

7. Montesano, R.; Vassalli, J.-D.; Baird, A.; Guillemin, R.; Orci, L. Basic fibroblast growth factor induces angiogenesis in vitro. Proc. Natl. Acad. Sci. USA 1986, 83, 7297-7301. [CrossRef] [PubMed]

8. Baum, O.; Suter, F.; Gerber, B.; Tschanz, S.A.; Buergy, R.; Blank, F.; Hlushchuk, R.; Djonov, V. VEGF-A Promotes Intussusceptive Angiogenesis in the Developing Chicken Chorioallantoic Membrane. Microcirculation 2010, 17, 447-457. [CrossRef] [PubMed]

9. Leker, R.R.; Toth, Z.E.; Shahar, T.; Cassiani-Ingoni, R.; Szalayova, I.; Key, S.; Bratincsák, A.; Mezey, E. Transforming growth factor $\alpha$ induces angiogenesis and neurogenesis following stroke. Neuroscience 2009, 163, 233-243. [CrossRef]

10. Yang, E.Y.; Moses, H.L. Transforming growth factor beta 1-induced changes in cell migration, proliferation, and angiogenesis in the chicken chorioallantoic membrane. J. Cell Biol. 1990, 111, 731-741. [CrossRef]

11. Bussolino, F.; Di Renzo, M.F.; Ziche, M.; Bocchietto, E.; Olivero, M.; Naldini, L.; Gaudino, G.; Tamagnone, L.; Coffer, A.; Comoglio, P. Hepatocyte growth factor is a potent angiogenic factor which stimulates endothelial cell motility and growth. J. Cell Biol. 1992, 119, 629-641. [CrossRef] [PubMed] 
12. Wang, L.; Chopp, M.; Teng, H.; Bolz, M.; Francisco, M.A.; Aluigi, D.M.; Wang, X.L.; Zhang, R.L.; Chrsitensen, S.; Sager, T.N. Tumor necrosis factor $\alpha$ primes cerebral endothelial cells for erythropoietin-induced angiogenesis. J. Cereb. Blood Flow Metab. 2011, 31, 640-647. [CrossRef]

13. Volpert, O.V.; Tolsma, S.S.; Pellerin, S.; Feige, J.-J.; Chen, H.; Mosher, D.F.; Bouck, N. Inhibition of angiogenesis by thrombospondin2. Biochem. Biophys. Res. Commun. 1995, 217, 326-332. [CrossRef] [PubMed]

14. O'Reilly, M.; Holmgren, L.; Shing, Y.; Chen, C.; Rosenthal, R.; Cao, Y.; Moses, M.; Lane, W.; Sage, E.; Folkman, J. Angiostatin: A Circulating Endothelial Cell Inhibitor That Suppresses Angiogenesis and Tumor Growth; Cold Spring Harbor Symposia on Quantitative Biology; Cold Spring Harbor Laboratory Press: Cold Spring Harbor, NY, USA, 1994; pp. 471-482.

15. O'Reilly, M.S.; Boehm, T.; Shing, Y.; Fukai, N.; Vasios, G.; Lane, W.S.; Flynn, E.; Birkhead, J.R.; Olsen, B.R.; Folkman, J. Endostatin: An endogenous inhibitor of angiogenesis and tumor growth. Cell 1997, 88, 277-285. [CrossRef]

16. Watanabe, K.; Hasegawa, Y.; Yamashita, H.; Shimizu, K.; Ding, Y.; Abe, M.; Ohta, H.; Imagawa, K.; Hojo, K.; Maki, H. Vasohibin as an endothelium-derived negative feedback regulator of angiogenesis. J. Clin. Investig. 2004, 114, 898-907. [CrossRef]

17. Deryugina, E.I.; Quigley, J.P. Chick embryo chorioallantoic membrane models to quantify angiogenesis induced by inflammatory and tumor cells or purified effector molecules. Methods Enzymol. 2008, 444, 21-41.

18. DeCicco-Skinner, K.L.; Henry, G.H.; Cataisson, C.; Tabib, T.; Gwilliam, J.C.; Watson, N.J.; Bullwinkle, E.M.; Falkenburg, L.; O’Neill, R.C.; Morin, A. Endothelial cell tube formation assay for the in vitro study of angiogenesis. J. Vis. Exp. 2014, e51312. [CrossRef] [PubMed]

19. Masson, V.; Devy, L.; Grignet-Debrus, C.; Bernt, S.; Bajou, K.; Blacher, S.; Roland, G.; Chang, Y.; Fong, T.; Carmeliet, P. Mouse aortic ring assay: A new approach of the molecular genetics of angiogenesis. Biol. Proced. Online 2002, 4, 24-31. [CrossRef]

20. Wartenberg, M.; Günther, J.; Hescheler, J.; Sauer, H. The embryoid body as a novel in vitro assay system for antiangiogenic agents. Lab. Investig. 1998, 78, 1301-1314. [PubMed]

21. Deckers, M.; van der Pluijm, G.; Dooijewaard, S.; Kroon, M.; van Hinsbergh, V.; Papapoulos, S.; Löwik, C. Effect of angiogenic and antiangiogenic compounds on the outgrowth of capillary structures from fetal mouse bone explants. Lab. Investig. 2001, 81, 5-15. [CrossRef] [PubMed]

22. Gimbrone, M.A., Jr.; Cotran, R.S.; Leapman, S.B.; Folkman, J. Tumor growth and neovascularization: An experimental model using the rabbit cornea. J. Natl. Cancer Inst. 1974, 52, 413-427. [CrossRef]

23. Norrby, K.; Jakobsson, A.; Sörbo, J. Mast-cell-mediated angiogenesis: A novel experimental model using the rat mesentery. Virchows Arch. B 1986, 52, 195-206. [CrossRef]

24. Lehr, H.-A.; Leunig, M.; Menger, M.D.; Nolte, D.; Messmer, K. Dorsal skinfold chamber technique for intravital microscopy in nude mice. Am. J. Pathol. 1993, 143, 1055. [PubMed]

25. Brown, J.L.; Cao, Z.A.; Pinzon-Ortiz, M.; Kendrew, J.; Reimer, C.; Wen, S.; Zhou, J.Q.; Tabrizi, M.; Emery, S.; McDermott, B. A human monoclonal anti-ANG2 antibody leads to broad antitumor activity in combination with VEGF inhibitors and chemotherapy agents in preclinical models. Mol. Cancer Ther. 2010, 9, 145-156. [CrossRef] [PubMed]

26. Kue, C.S.; Tan, K.Y.; LaM, M.L.; Lee, H.B. Chick embryo chorioallantoic membrane (CAM): An alternative predictive model in acute toxicological studies for anti-cancer drugs. Exp. Anim. 2015, 64, 129-138. [CrossRef] [PubMed]

27. Ribatti, D.; Vacca, A.; Roncali, L.; Dammacco, F. The chick embryo chorioallantoic membrane as a model for in vivo research on angiogenesis. Int. J. Dev. Biol. 1996, 40, 1189-1197. [CrossRef] [PubMed]

28. Dohle, D.S.; Pasa, S.D.; Gustmann, S.; Laub, M.; Wissler, J.H.; Jennissen, H.P.; Dünker, N. Chick ex ovo culture and ex ovo CAM assay: How it really works. J. Vis. Exp. 2009, e1620. [CrossRef]

29. Blacher, S.; Devy, L.; Hlushchuk, R.; Larger, E.; Lamandé, N.; Burri, P.; Corvol, P.; Djonov, V.; Foidart, J.-M.; Noël, A. Quantification of angiogenesis in the chicken chorioallantoic membrane (CAM). Image Anal. Stereol. 2005, 24, 169-180. [CrossRef]

30. Makanya, A.N.; Dimova, I.; Koller, T.; Styp-Rekowska, B.; Djonov, V. Dynamics of the developing chick chorioallantoic membrane assessed by stereology, allometry, immunohistochemistry and molecular analysis. PLoS ONE 2016, 11, e0152821. [CrossRef]

31. Russell, W.M.S.; Burch, R.L. The Principles of Humane Experimental Technique; Methuen \& Co., Ltd.: London, UK, 1959.

32. Ribatti, D.; Nico, B.; Vacca, A.; Presta, M. The gelatin sponge-chorioallantoic membrane assay. Nat. Protoc. 2006, 1, 85. [CrossRef]

33. Lokman, N.A.; Elder, A.S.; Ricciardelli, C.; Oehler, M.K. Chick chorioallantoic membrane (CAM) assay as an in vivo model to study the effect of newly identified molecules on ovarian cancer invasion and metastasis. Int. J. Mol. Sci. 2012, 13, 9959-9970. [CrossRef]

34. Hamburger, V.; Hamilton, H.L. A series of normal stages in the development of the chick embryo. J. Morphol. 1951, 88, 49-92. [CrossRef] [PubMed]

35. Chu, P.-Y.; Koh, A.P.-F.; Antony, J.; Huang, R.Y.-J. Applications of the Chick Chorioallantoic Membrane as an Alternative Model for Cancer Studies. Cells Tissues Organs 2021, 1-16. [CrossRef]

36. Ribatti, D. The chick embryo chorioallantoic membrane (CAM). A multifaceted experimental model. Mech. Dev. 2016, 141, 70-77. [CrossRef]

37. Barnhill, R.L.; Ryan, T.J. Biochemical modulation of angiogenesis in the chorioallantoic membrane of the chick embryo. J. Investig. Dermatol. 1983, 81, 485-488. [CrossRef] [PubMed]

38. Beckers, M.; Gladis-Villanueva, M.; Hamann, W.; Schmutzler, W.; Zwadlo-Klarwasser, G. The use of the chorio-allantoic membrane of the chick embryo as test for anti-inflammatory activity. Inflamm. Res. 1997, 46, 29-30. [CrossRef] 
39. Ribatti, D.; Frigeri, A.; Nico, B.; Nicchia, G.P.; De Giorgis, M.; Roncali, L.; Svelto, M. Aquaporin-1 expression in the chick embryo chorioallantoic membrane. Anat. Rec. 2002, 268, 85-89. [CrossRef]

40. Yar, M.; Shahzad, S.; Shahzadi, L.; Shahzad, S.A.; Mahmood, N.; Chaudhry, A.A.; ur Rehman, I.; MacNeil, S. Heparin binding chitosan derivatives for production of pro-angiogenic hydrogels for promoting tissue healing. Mater. Sci. Eng. C 2017, 74, 347-356. [CrossRef]

41. O’Dwyer, J.; Murphy, R.; González-Vázquez, A.; Kovarova, L.; Pravda, M.; Velebny, V.; Heise, A.; Duffy, G.P.; Cryan, S.A. Translational Studies on the Potential of a VEGF Nanoparticle-Loaded Hyaluronic Acid Hydrogel. Pharmaceutics 2021, 13, 779. [CrossRef] [PubMed]

42. Naik, M.; Brahma, P.; Dixit, M. A cost-effective and efficient chick ex-ovo CAM assay protocol to assess angiogenesis. Methods Protoc. 2018, 1, 19. [CrossRef] [PubMed]

43. Murphy, J.B. Transplantability of tissues to the embryo of foreign species: Its bearing on questions of tissue specificity and tumor immunity. J. Exp. Med. 1913, 17, 482-493. [CrossRef] [PubMed]

44. Nowak-Sliwinska, P.; Segura, T.; Iruela-Arispe, M.L. The chicken chorioallantoic membrane model in biology, medicine and bioengineering. Angiogenesis 2014, 17, 779-804. [CrossRef] [PubMed]

45. Ribatti, D.; Annese, T.; Tamma, R. The use of the chick embryo CAM assay in the study of angiogenic activiy of biomaterials. Microvasc. Res. 2020, 131, 104026. [CrossRef] [PubMed]

46. Zwadlo-Klarwasser, G.; Görlitz, K.; Hafemann, B.; Klee, D.; Klosterhalfen, B. The chorioallantoic membrane of the chick embryo as a simple model for the study of the angiogenic and inflammatory response to biomaterials. J. Mater. Sci. Mater. Med. 2001, 12, 195-199.

47. Tomanek, R.J.; Schatteman, G.C. Angiogenesis: New insights and therapeutic potential. Anat. Rec. 2000, 261, 126-135. [CrossRef]

48. Belle, J.; Ysasi, A.; Bennett, R.D.; Filipovic, N.; Nejad, M.I.; Trumper, D.L.; Ackermann, M.; Wagner, W.; Tsuda, A.; Konerding, M.A. Stretch-induced intussuceptive and sprouting angiogenesis in the chick chorioallantoic membrane. Microvasc. Res. 2014, 95, 60-67. [CrossRef]

49. Mangır, N.; Eke, G.; Hasirci, N.; Chapple, C.R.; Hasirci, V.; MacNeil, S. An estradiol releasing, proangiogenic hydrogel as a candidate material for use in soft tissue interposition. Neurourol. Urodyn. 2019, 38, 1195-1202. [CrossRef] [PubMed]

50. Sys, G.M.; Lapeire, L.; Stevens, N.; Favoreel, H.; Forsyth, R.; Bracke, M.; De Wever, O. The in ovo CAM-assay as a xenograft model for sarcoma. J. Vis. Exp. 2013, 77, e50522. [CrossRef]

51. Kleinman, H.K.; Martin, G.R. Matrigel: Basement Membrane Matrix with Biological Activity; Seminars in Cancer Biology; Elsevier: Amsterdam, The Netherlands, 2005; pp. 378-386.

52. Hughes, C.S.; Postovit, L.M.; Lajoie, G.A. Matrigel: A complex protein mixture required for optimal growth of cell culture. Proteomics 2010, 10, 1886-1890. [CrossRef]

53. Aisenbrey, E.A.; Murphy, W.L. Synthetic alternatives to Matrigel. Nat. Rev. Mater. 2020, 5, 539-551. [CrossRef] [PubMed]

54. Subauste, M.C.; Kupriyanova, T.A.; Conn, E.M.; Ardi, V.C.; Quigley, J.P.; Deryugina, E.I. Evaluation of metastatic and angiogenic potentials of human colon carcinoma cells in chick embryo model systems. Clin. Exp. Metastasis 2009, 26, 1033. [CrossRef]

55. Valiulytè, I.; Curkūnavičiūtè, R.; Ribokaitè, L.; Kazlauskas, A.; Vaitkevičiūtè, M.; Skauminas, K.; Valančiūtè, A. The Antitumorigenic activity of Sema3C in the chick embryo chorioallantoic membrane model. Int. J. Mol. Sci. 2019, 20, 5672. [CrossRef]

56. Hagenbuchner, J.; Rupp, M.; Salvador, C.; Meister, B.; Kiechl-Kohlendorfer, U.; Müller, T.; Geiger, K.; Sergi, C.; Obexer, P.; Ausserlechner, M.J. Nuclear FOXO3 predicts adverse clinical outcome and promotes tumor angiogenesis in neuroblastoma. Oncotarget 2016, 7, 77591. [CrossRef]

57. Kavaliauskaitè, D.; Stakišaitis, D.; Martinkutè, J.; Šlekienè, L.; Kazlauskas, A.; Balnytè, I.; Lesauskaitè, V.; Valančiūtė, A. The effect of sodium valproate on the glioblastoma 87 cell line tumor development on the chicken embryo chorioallantoic membrane and on EZH2 and p53 expression. BioMed Res. Int. 2017, 2017, 6326053. [CrossRef] [PubMed]

58. Hood, J.D.; Frausto, R.; Kiosses, W.B.; Schwartz, M.A.; Cheresh, D.A. Differential $\alpha$ v integrin-mediated Ras-ERK signaling during two pathways of angiogenesis. J. Cell Biol. 2003, 162, 933-943. [CrossRef]

59. Da Costa, P.M.; da Costa, M.P.; Carvalho, A.A.; Cavalcanti, S.M.T.; de Oliveira Cardoso, M.V.; de Oliveira Filho, G.B.; de Araújo Viana, D.; Fechine-Jamacaru, F.V.; Leite, A.C.L.; de Moraes, M.O. Improvement of in vivo anticancer and antiangiogenic potential of thalidomide derivatives. Chemico-Biol. Interact. 2015, 239, 174-183. [CrossRef] [PubMed]

60. Vimalraj, S.; Ashokkumar, T.; Saravanan, S. Biogenic gold nanoparticles synthesis mediated by Mangifera indica seed aqueous extracts exhibits antibacterial, anticancer and anti-angiogenic properties. Biomed. Pharmacother. 2018, 105, 440-448. [CrossRef] [PubMed]

61. Santos, C.J.; Ferreira Soares, D.C.; Ferreira, C.d.A.; de Barros, A.L.B.; Silva Cunha Junior, A.D.; Filho, F.M. Antiangiogenic evaluation of ZnWO4 nanoparticles synthesised through microwave-assisted hydrothermal method. J. Drug Target. 2018, 26, 806-817. [CrossRef] [PubMed]

62. Boyineni, J.; Tanpure, S.; Gnanamony, M.; Antony, R.; Fernández, K.S.; Lin, J.; Pinson, D.; Gondi, C.S. SPARC overexpression combined with radiation retards angiogenesis by suppressing VEGF-A via miR-410 in human neuroblastoma cells. Int. J. Oncol. 2016, 49, 1394-1406. [CrossRef] [PubMed]

63. Michaeli, S.; Dakwar, V.; Weidenfeld, K.; Granski, O.; Gilon, O.; Schif-Zuck, S.; Mamchur, A.; Shams, I.; Barkan, D. Soluble mediators produced by pro-resolving macrophages inhibit angiogenesis. Front. Immunol. 2018, 9, 768. [CrossRef] 
64. Lemmens, S.; Kusters, L.; Bronckaers, A.; Geurts, N.; Hendrix, S. The $\beta 2$-Adrenoceptor Agonist Terbutaline Stimulates Angiogenesis via Akt and ERK Signaling. J. Cell. Physiol. 2017, 232, 298-308. [CrossRef]

65. Torres, P.; Díaz, J.; Arce, M.; Silva, P.; Mendoza, P.; Lois, P.; Molina-Berríos, A.; Owen, G.I.; Palma, V.; Torres, V.A. The salivary peptide histatin-1 promotes endothelial cell adhesion, migration, and angiogenesis. FASEB J. 2017, 31, 4946-4958. [CrossRef] [PubMed]

66. Ribatti, D.; De Falco, G.; Nico, B.; Ria, R.; Crivellato, E.; Vacca, A. In vivo time-course of the angiogenic response induced by multiple myeloma plasma cells in the chick embryo chorioallantoic membrane. J. Anat. 2003, 203, 323-328. [CrossRef]

67. Shah, B.B.; Baksi, R.; Chaudagar, K.K.; Nivsarkar, M.; Mehta, A.A. Anti-leukemic and anti-angiogenic effects of d-Limonene on K562-implanted C57 BL/6 mice and the chick chorioallantoic membrane model. Anim. Models Exp. Med. 2018, 1, 328-333. [CrossRef] [PubMed]

68. Dewangan, J.; Kaushik, S.; Rath, S.K.; Balapure, A.K. Centchroman regulates breast cancer angiogenesis via inhibition of HIF-1 $\alpha$ /VEGFR2 signalling axis. Life Sci. 2018, 193, 9-19. [CrossRef]

69. Lamanuzzi, A.; Saltarella, I.; Desantis, V.; Frassanito, M.A.; Leone, P.; Racanelli, V.; Nico, B.; Ribatti, D.; Ditonno, P.; Prete, M. Inhibition of mTOR complex 2 restrains tumor angiogenesis in multiple myeloma. Oncotarget 2018, 9, 20563. [CrossRef] [PubMed]

70. Desantis, V.; Frassanito, M.A.; Tamma, R.; Saltarella, I.; Di Marzo, L.; Lamanuzzi, A.; Solimando, A.G.; Ruggieri, S.; Annese, T.; Nico, B. Rhu-Epo down-regulates pro-tumorigenic activity of cancer-associated fibroblasts in multiple myeloma. Ann. Hematol. 2018, 97, 1251-1258. [CrossRef]

71. Manjunathan, R.; Devarajan, N.; Ragunathan, M. Possible Mechanism of Human Recombinant Leptin-Induced VEGF A Synthesis via PI3K/Akt/mTOR/S6 Kinase Signaling Pathway while Inducing Angiogenesis: An Analysis Using Chicken Chorioallantoic Membrane Model. J. Vasc. Res. 2021, 58, 343-360. [CrossRef]

72. Gacche, R.; Meshram, R.; Shegokar, H.; Gond, D.; Kamble, S.; Dhabadge, V.; Utage, B.; Patil, K.; More, R. Flavonoids as a scaffold for development of novel anti-angiogenic agents: An experimental and computational enquiry. Arch. Biochem. Biophys. 2015, 577, 35-48. [CrossRef]

73. Kamble, S.; Utage, B.; Mogle, P.; Kamble, R.; Hese, S.; Dawane, B.; Gacche, R. Evaluation of curcumin capped copper nanoparticles as possible inhibitors of human breast cancer cells and angiogenesis: A comparative study with native curcumin. AAPS PharmSciTech 2016, 17, 1030-1041. [CrossRef] [PubMed]

74. Eke, G.; Mangir, N.; Hasirci, N.; MacNeil, S.; Hasirci, V. Development of a UV crosslinked biodegradable hydrogel containing adipose derived stem cells to promote vascularization for skin wounds and tissue engineering. Biomaterials 2017, 129, 188-198. [CrossRef] [PubMed]

75. Mangir, N.; Raza, A.; Haycock, J.W.; Chapple, C.; Macneil, S. An improved in vivo methodology to visualise tumour induced changes in vasculature using the chick chorionic allantoic membrane assay. In Vivo 2018, 32, 461-472. [PubMed]

76. Campbell, K.T.; Stilhano, R.S.; Silva, E.A. Enzymatically degradable alginate hydrogel systems to deliver endothelial progenitor cells for potential revasculature applications. Biomaterials 2018, 179, 109-121. [CrossRef]

77. Shahzad, S.A.; Yar, M.; Khan, Z.A.; Shahzadi, L.; Naqvi, S.A.R.; Mahmood, A.; Ullah, S.; Shaikh, A.J.; Sherazi, T.A.; Bale, A.T. Identification of 1, 2, 4-triazoles as new thymidine phosphorylase inhibitors: Future anti-tumor drugs. Bioorganic Chem. 2019, 85, 209-220. [CrossRef]

78. Papoutsi, M.; Sleeman, J.P.; Wilting, J. Interaction of rat tumor cells with blood vessels and lymphatics of the avian chorioallantoic membrane. Microsc. Res. Tech. 2001, 55, 100-107. [CrossRef] [PubMed]

79. Deryugina, E.I.; Zijlstra, A.; Partridge, J.J.; Kupriyanova, T.A.; Madsen, M.A.; Papagiannakopoulos, T.; Quigley, J.P. Unexpected effect of matrix metalloproteinase down-regulation on vascular intravasation and metastasis of human fibrosarcoma cells selected in vivo for high rates of dissemination. Cancer Res. 2005, 65, 10959-10969. [CrossRef] [PubMed]

80. Nik, M.E.; Malaekeh-Nikouei, B.; Amin, M.; Hatamipour, M.; Teymouri, M.; Sadeghnia, H.R.; Iranshahi, M.; Jaafari, M.R. Liposomal formulation of Galbanic acid improved therapeutic efficacy of pegylated liposomal Doxorubicin in mouse colon carcinoma. Sci. Rep. 2019, 9, 9527. [CrossRef] [PubMed]

81. Iranmanesh, M.; Mohebbati, R.; Forouzanfar, F.; Roshan, M.K.; Ghorbani, A.; Nik, M.J.; Soukhtanloo, M. In vivo and In vitro effects of ethanolic extract of Trigonella foenum-graecum L. seeds on proliferation, angiogenesis and tube formation of endothelial cells. Res. Pharm. Sci. 2018, 13, 343.

82. Nkembo, A.T.; Ntantie, E.; Salako, O.O.; Amissah, F.; Poku, R.A.; Latinwo, L.M.; Lamango, N.S. The antiangiogenic effects of polyisoprenylated cysteinyl amide inhibitors in HUVEC, chick embryo and zebrafish is dependent on the polyisoprenyl moiety. Oncotarget 2016, 7, 68194. [CrossRef] [PubMed]

83. Kumari, R.; Rawat, K.; Kumari, A.; Shrivastava, A. Amelioration of Dalton's lymphoma-induced angiogenesis by melatonin. Tumor Biol. 2017, 39, 1-17. [CrossRef] [PubMed]

84. Tan, G.; Onur, M.A. Cellular localization and biological effects of $20 \mathrm{~nm}$-gold nanoparticles. J. Biomed. Mater. Res. Part A 2018, 106 1708-1721. [CrossRef]

85. Weiss, A.; van Beijnum, J.R.; Bonvin, D.; Jichlinski, P.; Dyson, P.J.; Griffioen, A.W.; Nowak-Sliwinska, P. Low-dose angiostatic tyrosine kinase inhibitors improve photodynamic therapy for cancer: Lack of vascular normalization. J. Cell. Mol. Med. 2014, 18, 480-491. [CrossRef] [PubMed]

86. Yang, M.-Y.; Hung, C.-H.; Chang, C.-H.; Tseng, T.-H.; Wang, C.-J. Solanum nigrum suppress angiogenesis-mediated tumor growth through inhibition of the AKT/mTOR pathway. Am. J. Chin. Med. 2016, 44, 1273-1288. [CrossRef] [PubMed] 
87. Steinle, H.; Golombek, S.; Behring, A.; Schlensak, C.; Wendel, H.P.; Avci-Adali, M. Improving the angiogenic potential of EPCs via engineering with synthetic modified mRNAs. Mol. Ther. Nucleic Acids 2018, 13, 387-398. [CrossRef]

88. Liu, L.-Z.; Ding, M.; Zheng, J.Z.; Zhu, Y.; Fenderson, B.A.; Li, B.; Jing, J.Y.; Jiang, B.-H. Tungsten carbide-cobalt nanoparticles induce reactive oxygen species, AKT, ERK, AP-1, NF-kB, VEGF, and angiogenesis. Biol. Trace Elem. Res. 2015, $166,57-65$. [CrossRef] [PubMed]

89. Su, C.-M.; Wang, I.-C.; Liu, S.-C.; Sun, Y.; Jin, L.; Wang, S.-W.; Lee, H.-P.; Tseng, W.-P.; Tang, C.-H. Hypoxia induced mitogenic factor (HIMF) triggers angiogenesis by increasing interleukin-18 production in myoblasts. Sci. Rep. 2017, 7, 7393. [CrossRef] [PubMed]

90. Li, W.; Wang, Q.; Qi, X.; Lu, H.; Chen, Y.; Shi, J.; Wang, F.; Wang, Z.; Lu, Y.; Lu, Z. An oncogenic viral interferon regulatory factor upregulates CUB domain-containing protein 1 to promote angiogenesis by hijacking transcription factor lymphoid enhancer-binding factor 1 and metastasis suppressor CD82. Cell Death Differ. 2020, 27, 3289-3306. [CrossRef]

91. Adar, Y.; Stark, M.; Bram, E.E.; Nowak-Sliwinska, P.; Van Den Bergh, H.; Szewczyk, G.; Sarna, T.; Skladanowski, A.; Griffioen, A.; Assaraf, Y.G. Imidazoacridinone-dependent lysosomal photodestruction: A pharmacological Trojan horse approach to eradicate multidrug-resistant cancers. Cell Death Dis. 2012, 3, e293. [CrossRef]

92. Berndsen, R.H.; Castrogiovanni, C.; Weiss, A.; Rausch, M.; Dallinga, M.G.; Miljkovic-Licina, M.; Klaassen, I.; Meraldi, P.; van Beijnum, J.R.; Nowak-Sliwinska, P. Anti-angiogenic effects of crenolanib are mediated by mitotic modulation independently of PDGFR expression. Br. J. Cancer 2019, 121, 139-149. [CrossRef] [PubMed]

93. Carrillo, P.; Martínez-Poveda, B.; Cheng-Sánchez, I.; Guerra, J.; Tobia, C.; López-Romero, J.M.; Sarabia, F.; Medina, M.Á.; Quesada, A.R. Exploring the antiangiogenic potential of solomonamide A bioactive precursors: In vitro and in vivo evidences of the inhibitory activity of solo F-OH during angiogenesis. Mar. Drugs 2019, 17, 228. [CrossRef]

94. Dragostin, O.-M.; Tatia, R.; Samal, S.K.; Oancea, A.; Zamfir, A.S.; Dragostin, I.; Lisă, E.-L.; Apetrei, C.; Zamfir, C.L. Designing of Chitosan Derivatives Nanoparticles with Antiangiogenic Effect for Cancer Therapy. Nanomaterials 2020, 10, 698. [CrossRef]

95. Paterson, T.E.; Gigliobianco, G.; Sherborne, C.; Green, N.H.; Dugan, J.M.; MacNeil, S.; Reilly, G.C.; Claeyssens, F. Porous microspheres support mesenchymal progenitor cell ingrowth and stimulate angiogenesis. APL Bioeng. 2018, 2, 026103. [CrossRef] [PubMed]

96. Del Gaudio, C.; Crognale, V.; Serino, G.; Galloni, P.; Audenino, A.; Ribatti, D.; Morbiducci, U. Natural polymeric microspheres for modulated drug delivery. Mater. Sci. Eng. C 2017, 75, 408-417. [CrossRef] [PubMed]

97. Fergelot, P.; Bernhard, J.-C.; Soulet, F.; Kilarski, W.W.; Léon, C.; Courtois, N.; Deminiere, C.; Herbert, J.M.; Antczak, P.; Falciani, F. The experimental renal cell carcinoma model in the chick embryo. Angiogenesis 2013, 16, 181-194. [CrossRef]

98. Soares, D.C.F.; de Paula Oliveira, D.C.; Barcelos, L.S.; Barbosa, A.S.; Vieira, L.C.; Townsend, D.M.; Rubello, D.; de Barros, A.L.B.; Duarte, L.P.; Silva-Cunha, A. Antiangiogenic activity of PLGA-Lupeol implants for potential intravitreal applications. Biomed. Pharmacother. 2017, 92, 394-402. [CrossRef]

99. Doganci, S.; Yildirim, V.; Erol, G.; Yesildal, F.; Karabacak, K.; Kadan, M.; Ozkan, G.; Ince, M.; Ozgurtas, T. Polidocanol (Lauromacrogol 400) has anti-angiogenic effects in vitro and in vivo. Eur. Rev. Med. Pharmacol. Sci. 2016, 20, 1384-1389. [PubMed]

100. Seifaddinipour, M.; Farghadani, R.; Namvar, F.; Mohamad, J.; Abdul Kadir, H. Cytotoxic effects and anti-angiogenesis potential of pistachio (Pistacia vera L.) hulls against MCF-7 human breast cancer cells. Molecules 2018, 23, 110. [CrossRef] [PubMed]

101. Yang, Y.-C.; Chen, P.-N.; Wang, S.-Y.; Liao, C.-Y.; Lin, Y.-Y.; Sun, S.-R.; Chiu, C.-L.; Hsieh, Y.-S.; Shieh, J.-C.; Chang, J.T. The differential roles of Slit2-exon 15 splicing variants in angiogenesis and HUVEC permeability. Angiogenesis 2015, 18, 301-312. [CrossRef] [PubMed]

102. Hsieh, M.-J.; Liu, H.-T.; Wang, C.-N.; Huang, H.-Y.; Lin, Y.; Ko, Y.-S.; Wang, J.-S.; Chang, V.H.-S.; Pang, J.-H.S. Therapeutic potential of pro-angiogenic BPC157 is associated with VEGFR2 activation and up-regulation. J. Mol. Med. 2017, 95, 323-333. [CrossRef] [PubMed]

103. Chen, S.; Chen, L.H.; Niu, Y.H.; Geng, N.B.; Feng, C.J. AEG-1 promotes angiogenesis and may be a novel treatment target for tongue squamous cell carcinoma. Oral Dis. 2020, 26, 876-884. [CrossRef]

104. Winter, R.; Dungel, P.; Reischies, F.M.J.; Rohringer, S.; Slezak, P.; Smolle, C.; Spendel, S.; Kamolz, L.-P.; Ghaffari-Tabrizi-Wizsy, N.; Schicho, K. Photobiomodulation (PBM) promotes angiogenesis in-vitro and in chick embryo chorioallantoic membrane model. Sci. Rep. 2018, 8, 17080. [CrossRef]

105. Kim, H.J.; Ahn, M.-R. Apigenin Suppresses Angiogenesis by Inhibiting Tube Formation and Inducing Apoptosis. Nat. Prod. Commun. 2016, 11, 1433-1436. [CrossRef] [PubMed]

106. Oliveira, C.; Granja, S.; Neves, N.M.; Reis, R.L.; Baltazar, F.; Silva, T.H.; Martins, A. Fucoidan from Fucus vesiculosus inhibits new blood vessel formation and breast tumor growth in vivo. Carbohydr. Polym. 2019, 223, 115034. [CrossRef]

107. Bae, H.-S.; Kim, H.J.; Jeong, D.H.; Hosoya, T.; Kumazawa, S.; Jun, M.; Kim, O.-Y.; Kim, S.W.; Ahn, M.-R. In vitro and in vivo antiangiogenic activity of crowberry (Empetrum nigrum var. japonicum). Nat. Prod. Commun. 2016, 11. [CrossRef]

108. Hirsch, T.; Laemmle, C.; Behr, B.; Lehnhardt, M.; Jacobsen, F.; Hoefer, D.; Kueckelhaus, M. Implant for autologous soft tissue reconstruction using an adipose-derived stem cell-colonized alginate scaffold. J. Plast. Reconstr. Aesthetic Surg. 2018, 71, 101-111. [CrossRef] [PubMed]

109. He, R.-Q.; Li, X.-J.; Liang, L.; Xie, Y.; Luo, D.-Z.; Ma, J.; Peng, Z.-G.; Hu, X.-H.; Chen, G. The suppressive role of miR-542-5p in NSCLC: The evidence from clinical data and in vivo validation using a chick chorioallantoic membrane model. BMC Cancer 2017, 17, 655. [CrossRef] [PubMed] 
110. Gião, T.; Saavedra, J.; Vieira, J.R.; Pinto, M.T.; Arsequell, G.; Cardoso, I. Neuroprotection in early stages of Alzheimers Disease is promoted by Transthyretin angiogenic properties. Alzheimer's Res. Ther. 2021, 13, 143. [CrossRef]

111. Dikici, S.; Mangır, N.; Claeyssens, F.; Yar, M.; MacNeil, S. Exploration of 2-deoxy-D-ribose and 17 $\beta$-Estradiol as alternatives to exogenous VEGF to promote angiogenesis in tissue-engineered constructs. Regen. Med. 2019, 14, 179-197. [CrossRef] [PubMed]

112. Dikici, S.; Claeyssens, F.; MacNeil, S. Pre-Seeding of Simple Electrospun Scaffolds with a Combination of Endothelial Cells and Fibroblasts Strongly Promotes Angiogenesis. Tissue Eng. Regen. Med. 2020, 17, 445-458. [CrossRef]

113. Zavala, G.; Prieto, C.P.; Villanueva, A.A.; Palma, V. Sonic hedgehog (SHH) signaling improves the angiogenic potential of Wharton's jelly-derived mesenchymal stem cells (WJ-MSC). Stem Cell Res. Ther. 2017, 8, 203. [CrossRef]

114. Gagliardi, F.; Narayanan, A.; Gallotti, A.L.; Pieri, V.; Mazzoleni, S.; Cominelli, M.; Rezzola, S.; Corsini, M.; Brugnara, G.; Altabella, L. Enhanced SPARCL1 expression in cancer stem cells improves preclinical modeling of glioblastoma by promoting both tumor infiltration and angiogenesis. Neurobiol. Dis. 2020, 134, 104705. [CrossRef] [PubMed]

115. Strassburg, S.; Nienhueser, H.; Björn Stark, G.; Finkenzeller, G.; Torio-Padron, N. Co-culture of adipose-derived stem cells and endothelial cells in fibrin induces angiogenesis and vasculogenesis in a chorioallantoic membrane model. J. Tissue Eng. Regen. Med. 2016, 10, 496-506. [CrossRef]

116. Watchararot, T.; Prasongchean, W.; Thongnuek, P. Angiogenic property of silk fibroin scaffolds with adipose-derived stem cells on chick chorioallantoic membrane. R. Soc. Open Sci. 2021, 8, 201618. [CrossRef]

117. Shafaat, S.; Mangir, N.; Regureos, S.R.; Chapple, C.R.; MacNeil, S. Demonstration of improved tissue integration and angiogenesis with an elastic, estradiol releasing polyurethane material designed for use in pelvic floor repair. Neurourol. Urodyn. 2018, 37, 716-725. [CrossRef]

118. Choi, S.-W.; Lee, K.-S.; Lee, J.H.; Kang, H.J.; Lee, M.J.; Kim, H.Y.; Park, K.-I.; Kim, S.-L.; Shin, H.K.; Seo, W.D. Suppression of Akt-HIF-1 $\alpha$ signaling axis by diacetyl atractylodiol inhibits hypoxia-induced angiogenesis. BMB Rep. 2016, 49, 508. [CrossRef] [PubMed]

119. Lim, H.N.; Jang, J.-P.; Han, J.M.; Jang, J.-H.; Ahn, J.S.; Jung, H.J. Antiangiogenic potential of microbial metabolite elaiophylin for targeting tumor angiogenesis. Molecules 2018, 23, 563. [CrossRef]

120. Ahmad, S.; Ullah, F.; Ayaz, M.; Zeb, A.; Ullah, F.; Sadiq, A. Antitumor and anti-angiogenic potentials of isolated crude saponins and various fractions of Rumex hastatus D. Don. Biol. Res. 2016, 49, 18. [CrossRef] [PubMed]

121. Rabhi, C.; Arcile, G.; Cariel, L.; Lenoir, C.; Bignon, J.; Wdzieczak-Bakala, J.; Ouazzani, J. Antiangiogenic-like properties of fermented extracts of ayurvedic medicinal plants. J. Med. Food 2015, 18, 1065-1072. [CrossRef]

122. Klagsbrun, M.; Knighton, D.; Folkman, J. Tumor angiogenesis activity in cells grown in tissue culture. Cancer Res. 1976, 36, 110-114. [PubMed]

123. Knighton, D.; Ausprunk, D.; Tapper, D.; Folkman, J. Avascular and vascular phases of tumour growth in the chick embryo. Br. J. Cancer 1977, 35, 347-356. [CrossRef]

124. Pink, D.B.; Schulte, W.; Parseghian, M.H.; Zijlstra, A.; Lewis, J.D. Real-time visualization and quantitation of vascular permeability in vivo: Implications for drug delivery. PLOS ONE 2012, 7, e33760. [CrossRef]

125. Uloza, V.; Kuzminiene, A.; Palubinskiene, J.; Balnyte, I.; Uloziene, I.; Valanciute, A. Model of human recurrent respiratory papilloma on chicken embryo chorioallantoic membrane for tumor angiogenesis research. Histol. Histopathol. 2017, 32, 699-710. [PubMed]

126. Auerbach, R.; Kubai, L.; Sidky, Y. Angiogenesis induction by tumors, embryonic tissues, and lymphocytes. Cancer Res. 1976, 36, 3435-3440. [PubMed]

127. Murray, B.; Wilson, D. A study of metabolites as intermediate effectors in angiogenesis. Angiogenesis 2001, 4, 71-77. [CrossRef]

128. Samad, N.A.; Abdul, A.B.; Rahman, H.S.; Rasedee, A.; Ibrahim, T.A.T.; Keon, Y.S. Zerumbone suppresses angiogenesis in HepG2 cells through inhibition of matrix metalloproteinase-9, vascular endothelial growth factor, and vascular endothelial growth factor receptor expressions. Pharmacogn. Mag. 2017, 13 (Suppl. S4), S731.

129. Gurel-Gurevin, E.; Kiyan, H.T.; Esener, O.B.B.; Aydinlik, S.; Uvez, A.; Ulukaya, E.; Dimas, K.; Armutak, E.I. Chloroquine used in combination with chemotherapy synergistically suppresses growth and angiogenesis in vitro and in vivo. Anticancer Res. 2018, 38, 4011-4020. [CrossRef]

130. Wang, J.; Wang, Y.; Wang, Y.; Ma, Y.; Lan, Y.; Yang, X. Transforming growth factor $\beta$-regulated microRNA-29a promotes angiogenesis through targeting the phosphatase and tensin homolog in endothelium. J. Biol. Chem. 2013, 288, 10418-10426. [CrossRef]

131. Bushati, N.; Cohen, S.M. microRNA functions. Annu. Rev. Cell Dev. Biol. 2007, 23, 175-205. [CrossRef] [PubMed]

132. Anand, S. A brief primer on microRNAs and their roles in angiogenesis. Vasc. Cell 2013, 5, 2. [CrossRef]

133. Huang, C.; Luo, W.; Wang, Q.; Ye, Y.; Fan, J.; Lin, L.; Shi, C.; Wei, W.; Chen, H.; Wu, Y. Human mesenchymal stem cells promote ischemic repairment and angiogenesis of diabetic foot through exosome miRNA-21-5p. Stem Cell Res. 2021, 52, 102235. [CrossRef] [PubMed]

134. Roma-Rodrigues, C.; Fernandes, A.R.; Baptista, P.V. Counteracting the effect of leukemia exosomes by antiangiogenic gold nanoparticles. Int. J. Nanomed. 2019, 14, 6843. [CrossRef] [PubMed]

135. Forough, R.; Wang, X.; Martinez-Lemus, L.A.; Thomas, D.; Sun, Z.; Motamed, K.; Parker, J.L.; Meininger, G.A. Cell-based and direct gene transfer-induced angiogenesis via a secreted chimeric fibroblast growth factor-1 (sp-FGF-1) in the chick chorioallantoic membrane (CAM). Angiogenesis 2003, 6, 47-54. [CrossRef] [PubMed] 
136. Madrigal, J.L.; Sharma, S.N.; Campbell, K.T.; Stilhano, R.S.; Gijsbers, R.; Silva, E.A. Microgels produced using microfluidic on-chip polymer blending for controlled released of VEGF encoding lentivectors. Acta Biomater. 2018, 69, 265-276. [CrossRef]

137. Augustine, R.; Zahid, A.A.; Hasan, A.; Wang, M.; Webster, T.J. CTGF loaded electrospun dual porous core-shell membrane for diabetic wound healing. Int. J. Nanomed. 2019, 14, 8573. [CrossRef]

138. Lee, M.-S.; Ghim, J.; Kim, S.-J.; Yun, Y.S.; Yoo, S.-A.; Suh, P.-G.; Kim, W.-U.; Ryu, S.H. Functional interaction between CTGF and FPRL1 regulates VEGF-A-induced angiogenesis. Cell. Signal. 2015, 27, 1439-1448. [CrossRef]

139. Wilting, J.; Christ, B.; Weich, H.A. The effects of growth factors on the day 13 chorioallantoic membrane (CAM): A study of VEGF 165 and PDGF-BB. Anat. Embryol. 1992, 186, 251-257. [CrossRef]

140. Bai, Y.; Bai, L.; Zhou, J.; Chen, H.; Zhang, L. Sequential delivery of VEGF, FGF-2 and PDGF from the polymeric system enhance HUVECs angiogenesis in vitro and CAM angiogenesis. Cell. Immunol. 2018, 323, 19-32. [CrossRef]

141. Miller, W.J.; Kayton, M.L.; Patton, A.; O'Connor, S.; He, M.; Vu, H.; Baibakov, G.; Lorang, D.; Knezevic, V.; Kohn, E. A novel technique for quantifying changes in vascular density, endothelial cell proliferation and protein expression in response to modulators of angiogenesis using the chick chorioallantoic membrane (CAM) assay. J. Transl. Med. 2004, 2, 4. [CrossRef] [PubMed]

142. Li, W.; Yalcin, M.; Bharali, D.J.; Lin, Q.; Godugu, K.; Fujioka, K.; Keating, K.A.; Mousa, S.A. Pharmacokinetics, biodistribution, and anti-angiogenesis efficacy of diamino propane tetraiodothyroacetic acid-conjugated biodegradable polymeric nanoparticle. Sci. Rep. 2019, 9, 9006. [CrossRef] [PubMed]

143. Ma, J.; Wang, Q.; Fei, T.; Han, J.-D.J.; Chen, Y.-G. MCP-1 mediates TGF- $\beta$-induced angiogenesis by stimulating vascular smooth muscle cell migration. Blood 2007, 109, 987-994. [CrossRef] [PubMed]

144. Shanmuganathan, S.; Angayarkanni, N. Chebulagic acid Chebulinic acid and Gallic acid, the active principles of Triphala, inhibit $\mathrm{TNF} \alpha$ induced pro-angiogenic and pro-inflammatory activities in retinal capillary endothelial cells by inhibiting p38, ERK and NFkB phosphorylation. Vasc. Pharmacol. 2018, 108, 23-35. [CrossRef] [PubMed]

145. Taktak-Benamar, A.; Morjen, M.; Mabrouk, H.B.; Abdelmaksoud-Dammak, R.; Guerfali, M.; Fourati-Masmoudi, N.; Marrakchi, N.; Gargouri, A. Expression, purification and functionality of bioactive recombinant human vascular endothelial growth factor VEGF 165 in E. coli. AMB Express 2017, 7, 33. [CrossRef] [PubMed]

146. Hlushchuk, R.; Ehrbar, M.; Reichmuth, P.; Heinimann, N.; Styp-Rekowska, B.; Escher, R.; Baum, O.; Lienemann, P.; Makanya, A.; Keshet, E. Decrease in VEGF expression induces intussusceptive vascular pruning. Arterioscler. Thromb. Vasc. Biol. 2011, 31, 2836-2844. [CrossRef] [PubMed]

147. Wilting, J.; Birkenhäger, R.; Eichmann, A.; Kurz, H.; Martiny-Baron, G.; Marmé, D.; McCarthy, J.E.; Christ, B.; Weich, H.A. VEGF 121 Induces Proliferation of Vascular Endothelial Cells and Expression of flk-1 without Affecting Lymphatic Vessels of the Chorioallantoic Membrane. Dev. Biol. 1996, 176, 76-85. [CrossRef]

148. Abraham, S.; Rangaswamy, S.P.; Chinnaiah, A. Evaluation of recombinant human vascular endothelial growth factor VEGF 121-loaded poly-l-lactide microparticles as a controlled release delivery system. Turk. J. Biol. 2020, 44, 34-47.

149. Yum, S.; Jeong, S.; Kim, D.; Lee, S.; Kim, W.; Yoo, J.-W.; Kim, J.; Kwon, O.S.; Kim, D.-D.; Min, D.S. Minoxidil induction of VEGF is mediated by inhibition of HIF-prolyl hydroxylase. Int. J. Mol. Sci. 2018, 19, 53. [CrossRef]

150. Vázquez, F.; Hastings, G.; Ortega, M.-A.; Lane, T.F.; Oikemus, S.; Lombardo, M.; Iruela-Arispe, M.L. METH-1, a human ortholog of ADAMTS-1, and METH-2 are members of a new family of proteins with angio-inhibitory activity. J. Biol. Chem. 1999, 274, 23349-23357. [CrossRef]

151. Fernandez, M.; Bonkovsky, H.L. Vascular endothelial growth factor increases heme oxygenase-1 protein expression in the chick embryo chorioallantoic membrane. Br. J. Pharmacol. 2003, 139, 634-640. [CrossRef]

152. Campbell, K.T.; Hadley, D.J.; Kukis, D.L.; Silva, E.A. Alginate hydrogels allow for bioactive and sustained release of VEGF-C and VEGF-D for lymphangiogenic therapeutic applications. PLoS ONE 2017, 12, e0181484. [CrossRef]

153. Cao, Y.; Linden, P.; Farnebo, J.; Cao, R.; Eriksson, A.; Kumar, V.; Qi, J.-H.; Claesson-Welsh, L.; Alitalo, K. Vascular endothelial growth factor C induces angiogenesis in vivo. Proc. Natl. Acad. Sci. USA 1998, 95, 14389-14394. [CrossRef] [PubMed]

154. Malik, M.H.; Shahzadi, L.; Batool, R.; Safi, S.Z.; Khan, A.S.; Khan, A.F.; Chaudhry, A.A.; Rehman, I.U.; Yar, M. Thyroxine-loaded chitosan/carboxymethyl cellulose/hydroxyapatite hydrogels enhance angiogenesis in in-ovo experiments. Int. J. Biol. Macromol. 2020, 145, 1162-1170. [CrossRef]

155. Nikhil, K.; Sharan, S.; Wishard, R.; Palla, S.R.; Peddinti, R.K.; Roy, P. Pterostilbene carboxaldehyde thiosemicarbazone, a resveratrol derivative inhibits 17 $\beta$-Estradiol induced cell migration and proliferation in HUVECs. Steroids 2016, 108, 17-30. [CrossRef]

156. Pullar, C.E.; Le Provost, G.S.; O'leary, A.P.; Evans, S.E.; Baier, B.S.; Isseroff, R.R. $\beta 2 A R$ antagonists and $\beta 2 A R$ gene deletion both promote skin wound repair processes. J. Investig. Dermatol. 2012, 132, 2076-2084. [CrossRef] [PubMed]

157. Gho, Y.S.; Chae, C.-B. Anti-angiogenin activity of the peptides complementary to the receptor-binding site of angiogenin. J. Biol. Chem. 1997, 272, 24294-24299. [CrossRef]

158. Dusseau, J.W.; Hutchins, P.M.; Malbasa, D.S. Stimulation of angiogenesis by adenosine on the chick chorioallantoic membrane. Circ. Res. 1986, 59, 163-170. [CrossRef] [PubMed]

159. Oranger, A.; Brunetti, G.; Colaianni, G.; Tamma, R.; Carbone, C.; Lippo, L.; Mori, G.; Pignataro, P.; Cirulli, N.; Zerlotin, R. Sclerostin stimulates angiogenesis in human endothelial cells. Bone 2017, 101, 26-36. [CrossRef] [PubMed]

160. Zhang, Y.; Wang, Y.; Lu, Q.; Xin, W.; Cui, W.; Zhu, J. Organoarsenic roxarsone promotes angiogenesis in vivo. Basic Clin. Pharmacol. Toxicol. 2016, 118, 259-270. [CrossRef] 
161. Soucy, N.V.; Ihnat, M.A.; Kamat, C.D.; Hess, L.; Post, M.J.; Klei, L.R.; Clark, C.; Barchowsky, A. Arsenic stimulates angiogenesis and tumorigenesis in vivo. Toxicol. Sci. 2003, 76, 271-279. [CrossRef] [PubMed]

162. Augustine, R.; Dalvi, Y.B.; Nath, V.Y.; Varghese, R.; Raghuveeran, V.; Hasan, A.; Thomas, S.; Sandhyarani, N. Yttrium oxide nanoparticle loaded scaffolds with enhanced cell adhesion and vascularization for tissue engineering applications. Mater. Sci. Eng. C 2019, 103, 109801. [CrossRef]

163. Carmeliet, P.; Jain, R.K. Angiogenesis in cancer and other diseases. Nature 2000, 407, 249. [CrossRef]

164. Nishida, N.; Yano, H.; Nishida, T.; Kamura, T.; Kojiro, M. Angiogenesis in cancer. Vasc. Health Risk Manag. 2006, 2, 213. [CrossRef] [PubMed]

165. Gunasekaran, V.P.; Nishi, K.; Sivakumar, D.; Sivaraman, T.; Mathan, G. Identification of 2, 4-dihydroxy-5-pyrimidinyl imidothiocarbomate as a novel inhibitor to $\mathrm{Y}$ box binding protein-1 (YB-1) and its therapeutic actions against breast cancer. Eur. J. Pharm. Sci. 2018, 116, 2-14. [CrossRef]

166. Homayouni-Tabrizi, M.; Soltani, M.; Karimi, E.; Namvar, F.; Pouresmaeil, V.; Es-Haghi, A. Putative mechanism for anticancer properties of Ag-PP (NPs) extract. IET Nanobiotechnol. 2019, 13, 617-620. [CrossRef]

167. Ferrara, N.; Hillan, K.J.; Novotny, W. Bevacizumab (Avastin), a humanized anti-VEGF monoclonal antibody for cancer therapy. Biochem. Biophys. Res. Commun. 2005, 333, 328-335. [CrossRef] [PubMed]

168. Feflea, S.; Cimpean, A.M.; Ceausu, R.A.; Gaje, P.; Raica, M. Effects of antibodies to EG-VEGF on angiogenesis in the chick embryo chorioallantoic membrane. In Vivo 2012, 26, 793-797.

169. Vitaliti, A.; Wittmer, M.; Steiner, R.; Wyder, L.; Neri, D.; Klemenz, R. Inhibition of tumor angiogenesis by a single-chain antibody directed against vascular endothelial growth factor. Cancer Res. 2000, 60, 4311-4314.

170. Arezumand, R.; Mahdian, R.; Zeinali, S.; Hassanzadeh-Ghassabeh, G.; Mansouri, K.; Khanahmad, H.; Namvar-Asl, N.; Rahimi, H.; Behdani, M.; Cohan, R.A. Identification and characterization of a novel nanobody against human placental growth factor to modulate angiogenesis. Mol. Immunol. 2016, 78, 183-192. [CrossRef]

171. Sanz, L.; Kristensen, P.; Blanco, B.; Facteau, S.; Russell, S.; Winter, G.; Alvarez-Vallina, L. Single-chain antibody-based gene therapy: Inhibition of tumor growth by in situ production of phage-derived human antibody fragments blocking functionally active sites of cell-associated matrices. Gene Ther. 2002, 9, 1049-1053. [CrossRef]

172. Chiang, K.-C.; Sun, C.-C.; Chen, M.-H.; Huang, C.-Y.; Hsu, J.-T.; Yeh, T.-S.; Chen, L.-W.; Kuo, S.-F.; Juang, H.-H.; Takano, M. MART-10, the new brand of $1 \alpha, 25(\mathrm{OH}) 2 \mathrm{D} 3$ analog, is a potent anti-angiogenic agent in vivo and in vitro. J. Steroid Biochem. Mol. Biol. 2016, 155, 26-34. [CrossRef]

173. Kim, A.; Ma, J.Y. Rhaponticin decreases the metastatic and angiogenic abilities of cancer cells via suppression of the HIF- $1 \alpha$ pathway. Int. J. Oncol. 2018, 53, 1160-1170. [CrossRef] [PubMed]

174. Azhar, A.; Khan, M.S.; Swaminathan, A.; Naseem, A.; Chatterjee, S.; Jairajpuri, M.A. Oxidized antithrombin is a dual inhibitor of coagulation and angiogenesis: Importance of low heparin affinity. Int. J. Biol. Macromol. 2016, 82, 541-550. [CrossRef]

175. Babae, N.; Bourajjaj, M.; Liu, Y.; Van Beijnum, J.R.; Cerisoli, F.; Scaria, P.V.; Verheul, M.; Van Berkel, M.P.; Pieters, E.H.; Van Haastert, R.J. Systemic miRNA-7 delivery inhibits tumor angiogenesis and growth in murine xenograft glioblastoma. Oncotarget 2014, 5, 6687. [CrossRef] [PubMed]

176. Brandwijk, R.J.; Nesmelova, I.; Dings, R.P.; Mayo, K.H.; Thijssen, V.L.; Griffioen, A.W. Cloning an artificial gene encoding angiostatic anginex: From designed peptide to functional recombinant protein. Biochem. Biophys. Res. Commun. 2005, 333, 1261-1268. [CrossRef]

177. Griffioen, A.; van der Schaft, D.; Barendsz-Janson, A.; Cox, A.; Boudier, H.S.; Hillen, H.; Mayo, K. Anginex, a designed peptide that inhibits angiogenesis. Biochem. J. 2001, 354, 233-242. [CrossRef] [PubMed]

178. Célérier, J.; Cruz, A.; Lamandé, N.; Gasc, J.-M.; Corvol, P. Angiotensinogen and its cleaved derivatives inhibit angiogenesis. Hypertension 2002, 39, 224-228. [CrossRef] [PubMed]

179. Ghazaryan, N.; Movsisyan, N.; Macedo, J.C.; Vaz, S.; Ayvazyan, N.; Pardo, L.; Logarinho, E. The antitumor efficacy of monomeric disintegrin obtustatin in S-180 sarcoma mouse model. Investig. New Drugs 2019, 37, 1044-1051. [CrossRef]

180. Loizzi, V.; Del Vecchio, V.; Gargano, G.; De Liso, M.; Kardashi, A.; Naglieri, E.; Resta, L.; Cicinelli, E.; Cormio, G. Biological pathways involved in tumor angiogenesis and bevacizumab based anti-angiogenic therapy with special references to ovarian cancer. Int. J. Mol. Sci. 2017, 18, 1967. [CrossRef] [PubMed]

181. Chaplain, M. The mathematical modelling of tumour angiogenesis and invasion. Acta Biotheor. 1995, 43, 387-402. [CrossRef] [PubMed]

182. Hanahan, D.; Weinberg, R.A. Hallmarks of cancer: The next generation. Cell 2011, 144, 646-674. [CrossRef]

183. Becker, J.; Covelo-Fernandez, A.; von Bonin, F.; Kube, D.; Wilting, J. Specific tumor-stroma interactions of EBV-positive Burkitt's lymphoma cells in the chick chorioallantoic membrane. Vasc. Cell 2012, 4, 3. [CrossRef]

184. Vilahur, G.; Oñate, B.; Cubedo, J.; Béjar, M.T.; Arderiu, G.; Peña, E.; Casaní, L.; Gutiérrez, M.; Capdevila, A.; Pons-Lladó, G. Allogenic adipose-derived stem cell therapy overcomes ischemia-induced microvessel rarefaction in the myocardium: Systems biology study. Stem Cell Res. Ther. 2017, 8, 52. [CrossRef]

185. Reuter, A.; Sckell, A.; Brandenburg, L.-O.; Burchardt, M.; Kramer, A.; Stope, M.B. Overexpression of MicroRNA-1 in Prostate Cancer Cells Modulates the Blood Vessel System of an In Vivo Hen's Egg Test-Chorioallantoic Membrane Model. In Vivo 2019, 33 41-46. [CrossRef] 
186. Wolint, P.; Bopp, A.; Woloszyk, A.; Tian, Y.; Evrova, O.; Hilbe, M.; Giovanoli, P.; Calcagni, M.; Hoerstrup, S.P.; Buschmann, J. Cellular self-assembly into 3D microtissues enhances the angiogenic activity and functional neovascularization capacity of human cardiopoietic stem cells. Angiogenesis 2019, 22, 37-52. [CrossRef] [PubMed]

187. Ribatti, D.; Nico, B.; Cimpean, A.M.; Raica, M.; Crivellato, E.; Ruggieri, S.; Vacca, A. B16-F10 melanoma cells contribute to the new formation of blood vessels in the chick embryo chorioallantoic membrane through vasculogenic mimicry. Clin. Exp. Med. 2013, 13, 143-147. [CrossRef] [PubMed]

188. Isachenko, V.; Mallmann, P.; Petrunkina, A.M.; Rahimi, G.; Nawroth, F.; Hancke, K.; Felberbaum, R.; Genze, F.; Damjanoski, I.; Isachenko, E. Comparison of in vitro-and chorioallantoic membrane (CAM)-culture systems for cryopreserved medulla-contained human ovarian tissue. PLoS ONE 2012, 7, e32549. [CrossRef] [PubMed]

189. Kunzi-Rapp, K.; Kaskel, P.; Steiner, R.; Uwe Peter, R.; Krahn, G. Increased blood levels of Human S100 in melanoma chick embryo xenografts' circulation. Pigment Cell Res. 2001, 14, 9-13. [CrossRef] [PubMed]

190. Marzullo, A.; Vacca, A.; Roncali, L.; Pollice, L.; Ribatti, D. Angiogenesis in hepatocellular carcinoma: An experimental study in the chick embryo chorioallantoic membrane. Int. J. Oncol. 1998, 13, 17-38. [CrossRef]

191. Ismail, M.; Torsten, U.; Dressler, C.; Diederichs, J.; Hüske, S.; Weitzel, H.; Berlien, H.-P. Photodynamic therapy of malignant ovarian tumours cultivated on CAM. Lasers Med. Sci. 1999, 14, 91-96. [CrossRef]

192. Jiang, W.; Zhu, P.; Zhang, T.; Liao, F.; Yu, Y.; Liu, Y.; Shen, H.; Zhao, Z.; Huang, X.; Zhou, N. MicroRNA-205 mediates endothelial progenitor functions in distraction osteogenesis by targeting the transcription regulator NOTCH2. Stem Cell Res. Ther. 2021, 12, 101. [CrossRef]

193. Huang, C.-C.; Tseng, T.-T.; Liu, S.-C.; Lin, Y.-Y.; Law, Y.-Y.; Hu, S.-L.; Wang, S.-W.; Tsai, C.-H.; Tang, C.-H. S1P Increases VEGF Production in Osteoblasts and Facilitates Endothelial Progenitor Cell Angiogenesis by Inhibiting miR-16-5p Expression via the c-Src/FAK Signaling Pathway in Rheumatoid Arthritis. Cells 2021, 10, 2168. [CrossRef]

194. Zhang, T.; Liu, W.; Zeng, X.-C.; Jiang, N.; Fu, B.-S.; Guo, Y.; Yi, H.-M.; Li, H.; Zhang, Q.; Chen, W.-J. Down-regulation of microRNA-338-3p promoted angiogenesis in hepatocellular carcinoma. Biomed. Pharmacother. 2016, 84, 583-591. [CrossRef] [PubMed]

195. Wu, S.; Yu, W.; Qu, X.; Wang, R.; Xu, J.; Zhang, Q.; Xu, J.; Li, J.; Chen, L. Argonaute 2 promotes myeloma angiogenesis via microRNA dysregulation. J. Hematol. Oncol. 2014, 7, 40. [CrossRef] [PubMed]

196. Liu, Y.; Han, Z.-P.; Zhang, S.-S.; Jing, Y.-Y.; Bu, X.-X.; Wang, C.-Y.; Sun, K.; Jiang, G.-C.; Zhao, X.; Li, R. Effects of inflammatory factors on mesenchymal stem cells and their role in the promotion of tumor angiogenesis in colon cancer. J. Biol. Chem. 2011, 286, 25007-25015. [CrossRef] [PubMed]

197. Zacchigna, S.; Zentilin, L.; Morini, M.; Dell'Eva, R.; Noonan, D.M.; Albini, A.; Giacca, M. AAV-mediated gene transfer of tissue inhibitor of metalloproteinases-1 inhibits vascular tumor growth and angiogenesis in vivo. Cancer Gene Ther. 2004, 11, 73-80. [CrossRef] [PubMed]

198. Zhou, J.; Zhang, Z.; Zhao, H.; Zhu, D.; Zhang, Y.; Li, D. Anti-angiogenesis by lentivirus-mediated small interfering RNA silencing of angiopoietin-2 gene in pancreatic carcinoma. Technol. Cancer Res. Treat. 2011, 10, 361-369. [CrossRef]

199. Liu, S.-C.; Chuang, S.; Hsu, C.; Tsai, C.; Wang, S.; Tang, C. CTGF increases vascular endothelial growth factor-dependent angiogenesis in human synovial fibroblasts by increasing miR-210 expression. Cell Death Dis. 2014, 5, e1485. [CrossRef] [PubMed]

200. Li, J.; Dong, X.; Xu, Z.; Jiang, X.; Jiang, H.; Krissansen, G.W.; Sun, X. Endostatin gene therapy enhances the efficacy of paclitaxel to suppress breast cancers and metastases in mice. J. Biomed. Sci. 2008, 15, 99-109. [CrossRef] [PubMed]

201. Gu, M.; Zhang, K.; Yao, H.-J.; Zhou, J.; Peng, Y.-B.; Xu, M.-X.; Wang, Z. RNAi-mediated knockdown of vascular endothelial growth factor inhibits vascularization and tumor growth in renal cell carcinoma. Int. J. Mol. Med. 2015, 36, 1063-1072. [CrossRef]

202. Liu, G.-T.; Huang, Y.-L.; Tzeng, H.-E.; Tsai, C.-H.; Wang, S.-W.; Tang, C.-H. CCL5 promotes vascular endothelial growth factor expression and induces angiogenesis by down-regulating miR-199a in human chondrosarcoma cells. Cancer Lett. 2015, 357, 476-487. [CrossRef] [PubMed]

203. Xiao, T.; Fan, J.K.; Huang, H.L.; Gu, J.F.; Li, L.-Y.; Liu, X.Y. VEGI-armed oncolytic adenovirus inhibits tumor neovascularization and directly induces mitochondria-mediated cancer cell apoptosis. Cell Res. 2010, 20, 367-378. [CrossRef]

204. Hu, C.C.; Ji, H.M.; Chen, S.L.; Zhang, H.W.; Wang, B.Q.; Zhou, L.Y.; Zhang, Z.P.; Sun, X.L.; Chen, Z.Z.; Cai, Y.Q. Investigation of a plasmid containing a novel immunotoxin VEGF165-PE38 gene for antiangiogenic therapy in a malignant glioma model. Int. J. Cancer 2010, 127, 2222-2229. [CrossRef] [PubMed]

205. Li, Y.; Kuscu, C.; Banach, A.; Zhang, Q.; Pulkoski-Gross, A.; Kim, D.; Liu, J.; Roth, E.; Li, E.; Shroyer, K.R. miR-181a-5p inhibits cancer cell migration and angiogenesis via downregulation of matrix metalloproteinase-14. Cancer Res. 2015, 75, 2674-2685. [CrossRef] [PubMed]

206. Kim, T.-H.; Hur, E.-g.; Kang, S.-J.; Kim, J.-A.; Thapa, D.; Lee, Y.M.; Ku, S.K.; Jung, Y.; Kwak, M.-K. NRF2 blockade suppresses colon tumor angiogenesis by inhibiting hypoxia-induced activation of HIF-1 $\alpha$. Cancer Res. 2011, 71, 2260-2275. [CrossRef] [PubMed]

207. Bernard, H.; Garmy-Susini, B.; Ainaoui, N.; Van Den Berghe, L.; Peurichard, A.; Javerzat, S.; Bikfalvi, A.; Lane, D.P.; Bourdon, J.-C.; Prats, A.-C. The p53 isoform, $\Delta 133$ p53 $\alpha$, stimulates angiogenesis and tumour progression. Oncogene 2013, 32, $2150-2160$. [CrossRef] [PubMed] 
208. Xu, S.; Guo, R.; Li, P.Z.; Li, K.; Yan, Y.; Chen, J.; Wang, G.; Brand-Saberi, B.; Yang, X.; Cheng, X. Dexamethasone interferes with osteoblasts formation during osteogenesis through altering IGF-1-mediated angiogenesis. J. Cell. Physiol. 2019, $234,15167-15181$. [CrossRef]

209. Rao, D.D.; Vorhies, J.S.; Senzer, N.; Nemunaitis, J. siRNA vs. shRNA: Similarities and differences. Adv. Drug Deliv. Rev. 2009, 61, 746-759. [CrossRef] [PubMed]

210. Balke, M.; Neumann, A.; Kersting, C.; Agelopoulos, K.; Gebert, C.; Gosheger, G.; Buerger, H.; Hagedorn, M. Morphologic characterization of osteosarcoma growth on the chick chorioallantoic membrane. BMC Res. Notes 2010, 3, 58. [CrossRef]

211. Jilani, S.M.; Murphy, T.J.; Thai, S.N.; Eichmann, A.; Alva, J.A.; Iruela-Arispe, M.L. Selective binding of lectins to embryonic chicken vasculature. J. Histochem. Cytochem. 2003, 51, 597-604. [CrossRef]

212. Shereema, R.; Sruthi, T.; Kumar, V.S.; Rao, T.; Shankar, S.S. Angiogenic profiling of synthesized carbon quantum dots. Biochemistry 2015, 54, 6352-6356. [CrossRef]

213. Isachenko, V.; Orth, I.; Isachenko, E.; Mallmann, P.; Peters, D.; Schmidt, T.; Morgenstern, B.; Foth, D.; Hanstein, B.; Rahimi, G. Viability of human ovarian tissue confirmed 5 years after freezing with spontaneous ice-formation by autografting and chorio-allantoic membrane culture. Cryobiology 2013, 66, 233-238. [CrossRef] [PubMed]

214. Larger, E.; Marre, M.; Corvol, P.; Gasc, J.-M. Hyperglycemia-induced defects in angiogenesis in the chicken chorioallantoic membrane model. Diabetes 2004, 53, 752-761. [CrossRef]

215. Kleibeuker, E.A.; ten Hooven, M.A.; Castricum, K.C.; Honeywell, R.; Griffioen, A.W.; Verheul, H.M.; Slotman, B.J.; Thijssen, V.L. Optimal treatment scheduling of ionizing radiation and sunitinib improves the antitumor activity and allows dose reduction. Cancer Med. 2015, 4, 1003-1015. [CrossRef]

216. Jiang, X.; Xiong, Q.; Xu, G.; Lin, H.; Fang, X.; Cui, D.; Xu, M.; Chen, F.; Geng, H. VEGF-loaded nanoparticle-modified BAMAs enhance angiogenesis and inhibit graft shrinkage in tissue-engineered bladder. Ann. Biomed. Eng. 2015, 43, 2577-2586. [CrossRef] [PubMed]

217. Brash, J.T.; Ruhrberg, C.; Fantin, A. Evaluating vascular hyperpermeability-inducing agents in the skin with the Miles assay. $J$. Vis. Exp. 2018, 136, 57524. [CrossRef] [PubMed]

218. Rizzo, V.; Kim, D.; Durán, W.N.; DeFouw, D.O. Ontogeny of microvascular permeability to macromolecules in the chick chorioallantoic membrane during normal angiogenesis. Microvasc. Res. 1995, 49, 49-63. [CrossRef] [PubMed]

219. Rizzo, V.; DeFouw, D.O. Capillary sprouts restrict macromolecular extravasation during normal angiogenesis in the chick chorioallantoic membrane. Microvasc. Res. 1996, 52, 47-57. [CrossRef] [PubMed]

220. Rizzo, V.; De Fouw, D. Microvascular permselectivity in the chick chorioallantoic membrane during endothelial cell senescence. Int. J. Microcirc. 1997, 17, 75-79. [CrossRef]

221. Saleh, A.I.; Mohamed, I.; Mohamed, A.A.; Abdelkader, M.; Yalcin, H.C.; Aboulkassim, T.; Batist, G.; Yasmeen, A.; Moustafa, A.-E.A. Elaeagnus angustifolia plant extract inhibits angiogenesis and downgrades cell invasion of human oral cancer cells via Erk1/Erk2 inactivation. Nutr. Cancer 2018, 70, 297-305. [CrossRef]

222. Aanhane, E.; Schulkens, I.A.; Heusschen, R.; Castricum, K.; Leffler, H.; Griffioen, A.W.; Thijssen, V.L. Different angioregulatory activity of monovalent galectin-9 isoforms. Angiogenesis 2018, 21, 545-555. [CrossRef]

223. Borjan, B.; Steiner, N.; Karbon, S.; Kern, J.; Francesch, A.; Hermann, M.; Willenbacher, W.; Gunsilius, E.; Untergasser, G. The Aplidin analogs PM01215 and PM02781 inhibit angiogenesis in vitro and in vivo. BMC Cancer 2015, 15, 738. [CrossRef]

224. Heuberger, D.M.; Harankhedkar, S.; Morgan, T.; Wolint, P.; Calcagni, M.; Lai, B.; Fahrni, C.J.; Buschmann, J. High-affinity Cu (I) chelator PSP-2 as potential anti-angiogenic agent. Sci. Rep. 2019, 9, 14055. [CrossRef]

225. Melkonian, G.; Munoz, N.; Chung, J.; Tong, C.; Marr, R.; Talbot, P. Capillary plexus development in the day five to day six chick chorioallantoic membrane is inhibited by cytochalasin D and ssuramin. J. Exp. Zool. 2002, 292, 241-254. [CrossRef]

226. Magalhães, L.F.; Mello-Andrade, F.; Pires, W.C.; Silva, H.D.; da Silva, P.F.F.; Macedo, L.M.; de Castro, C.H.; Carneiro, C.C.; Cardoso, C.G.; de Melo Reis, P.R. cis-[RuCl (BzCN)(bipy)(dppe)] PF6 induces anti-angiogenesis and apoptosis by a mechanism of caspase-dependent involving DNA damage, PARP activation, and Tp53 induction in Ehrlich tumor cells. Chemico-Biol. Interact. 2017, 278, 101-113. [CrossRef]

227. Prieto, C.P.; Ortiz, M.C.; Villanueva, A.; Villarroel, C.; Edwards, S.S.; Elliott, M.; Lattus, J.; Aedo, S.; Meza, D.; Lois, P. Netrin-1 acts as a non-canonical angiogenic factor produced by human Wharton's jelly mesenchymal stem cells (WJ-MSC). Stem Cell Res. Ther. 2017, 8, 43. [CrossRef]

228. de Castro, J.V.; Gomes, E.D.; Granja, S.; Anjo, S.I.; Baltazar, F.; Manadas, B.; Salgado, A.J.; Costa, B.M. Impact of mesenchymal stem cells' secretome on glioblastoma pathophysiology. J. Transl. Med. 2017, 15, 200. [CrossRef]

229. Rizzo, V.; Defouw, D.O. Mast cell activation accelerates the normal rate of angiogenesis in the chick chorioallantoic membrane. Microvasc. Res. 1996, 52, 245-257. [CrossRef] [PubMed]

230. Burggren, W.; Rojas Antich, M. Angiogenesis in the Avian Embryo Chorioallantoic Membrane: A Perspective on Research Trends and a Case Study on Toxicant Vascular Effects. J. Cardiovasc. Dev. Dis. 2020, 7, 56. [CrossRef]

231. DeFouw, D.O.; Rizzo, V.J.; Steinfeld, R.; Feinberg, R.N. Mapping of the microcirculation in the chick chorioallantoic membrane during normal angiogenesis. Microvasc. Res. 1989, 38, 136-147. [CrossRef]

232. Dimitropoulou, C.; Malkusch, W.; Fait, E.; Maragoudakis, M.; Konerding, M. The vascular architecture of the chick chorioallantoic membrane: Sequential quantitative evaluation using corrosion casting. Angiogenesis 1998, 2, 255-263. [CrossRef] 
233. Cornillie, P.; Casteleyn, C.; von Horst, C.; Henry, R. Corrosion casting in anatomy: Visualizing the architecture of hollow structures and surface details. Anatomia Histol. Embryol. 2019, 48, 591-604. [CrossRef] [PubMed]

234. Hossler, F.E.; Douglas, J.E. Vascular corrosion casting: Review of advantages and limitations in the application of some simple quantitative methods. Microsc. Microanal. 2001, 7, 253-264. [CrossRef]

235. Ackermann, M.; Konerding, M.A. Vascular casting for the study of vascular morphogenesis. In Vascular Morphogenesis; Springer: Berlin/Heidelberg, Germany, 2015; pp. 49-66.

236. Krucker, T.; Lang, A.; Meyer, E.P. New polyurethane-based material for vascular corrosion casting with improved physical and imaging characteristics. Microsc. Res. Tech. 2006, 69, 138-147. [CrossRef] [PubMed]

237. Djonov, V.G.; Kurz, H.; Burri, P.H. Optimality in the developing vascular system: Branching remodeling by means of intussusception as an efficient adaptation mechanism. Dev. Dyn. 2002, 224, 391-402. [CrossRef]

238. Siamblis, D.; Karnabatidis, D.; Hatjikondi, O.; Kalogeropoulou, C.; Kardamakis, D.; Dimopoulos, J. A novel radiological approach for the experimental study of angiogenesis: Angiography of the chick embryo and its chorioallantoic membrane. Eur. J. Radiol. 1996, 21, 220-224. [CrossRef]

239. Nikiforidis, G.; Papazafiropoulos, D.; Siablis, D.; Karnabatidis, D.; Hatjikondi, O.; Dimopoulos, J. Quantitative assessment of angiogenesis in the chick embryo and its chorioallantoic membrane by computerised analysis of angiographic images. Eur. J. Radiol. 1999, 29, 168-179. [CrossRef]

240. Rovithi, M.; Avan, A.; Funel, N.; Leon, L.G.; Gomez, V.E.; Wurdinger, T.; Griffioen, A.W.; Verheul, H.M.; Giovannetti, E. Development of bioluminescent chick chorioallantoic membrane (CAM) models for primary pancreatic cancer cells: A platform for drug testing. Sci. Rep. 2017, 7, 44686. [CrossRef]

241. Zhang, P.; Zhong, S.; Wang, G.; Zhang, S.-Y.; Chu, C.; Zeng, S.; Yan, Y.; Cheng, X.; Bao, Y.; Hocher, B. N-acetylcysteine suppresses LPS-induced pathological angiogenesis. Cell. Physiol. Biochem. 2018, 49, 2483-2495. [CrossRef] [PubMed]

242. Maacha, S.; Saule, S. Evaluation of tumor cell invasiveness in vivo: The chick chorioallantoic membrane assay. In Cell Migration; Humana Press: New York, NY, USA, 2018; pp. 71-77.

243. Cardelli, M. Alu pcr. In PCR Protocols; Springer: Berlin/Heidelberg, Germany, 2011; pp. 221-229.

244. Mira, E.; Lacalle, R.A.; Gómez-Moutón, C.; Leonardo, E.; Mañes, S. Quantitative determination of tumor cell intravasation in a real-time polymerase chain reaction-based assay. Clin. Exp. Metastasis 2002, 19, 313-318. [CrossRef] [PubMed]

245. Kim, J.; Yu, W.; Kovalski, K.; Ossowski, L. Requirement for specific proteases in cancer cell intravasation as revealed by a novel semiquantitative PCR-based assay. Cell 1998, 94, 353-362. [CrossRef]

246. Zijlstra, A.; Mellor, R.; Panzarella, G.; Aimes, R.T.; Hooper, J.D.; Marchenko, N.D.; Quigley, J.P. A quantitative analysis of rate-limiting steps in the metastatic cascade using human-specific real-time polymerase chain reaction. Cancer Res. 2002, 62, 7083-7092. [PubMed]

247. Horst, E.H.v.d.; Leupold, J.H.; Schubbert, R.; Ullrich, A.; Allgayer, H. TaqMan ${ }^{\circledR}$-based quantification of invasive cells in the chick embryo metastasis assay. Biotechniques 2004, 37, 940-946. [CrossRef] [PubMed]

248. Zijlstra, A.; Seandel, M.; Kupriyanova, T.A.; Partridge, J.J.; Madsen, M.A.; Hahn-Dantona, E.A.; Quigley, J.P.; Deryugina, E.I. Proangiogenic role of neutrophil-like inflammatory heterophils during neovascularization induced by growth factors and human tumor cells. Blood 2006, 107, 317-327. [CrossRef]

249. Mangieri, D.; Nico, B.; Benagiano, V.; De Giorgis, M.; Vacca, A.; Ribatti, D. Angiogenic activity of multiple myeloma endothelial cells in vivo in the chick embryo chorioallantoic membrane assay is associated to a down-regulation in the expression of endogenous endostatin. J. Cell. Mol. Med. 2008, 12, 1023-1028. [CrossRef] [PubMed]

250. Ribatti, D.; Urbinati, C.; Nico, B.; Rusnati, M.; Roncali, L.; Presta, M. Endogenous basic fibroblast growth factor is implicated in the vascularization of the chick embryo chorioallantoic membrane. Dev. Biol. 1995, 170, 39-49. [CrossRef]

251. Eliceiri, B.P.; Klemke, R.; Strömblad, S.; Cheresh, D.A. Integrin $\alpha \mathrm{v} \beta 3$ requirement for sustained mitogen-activated protein kinase activity during angiogenesis. J. Cell Biol. 1998, 140, 1255-1263. [CrossRef]

252. Brooks, P.C.; Silletti, S.; von Schalscha, T.L.; Friedlander, M.; Cheresh, D.A. Disruption of angiogenesis by PEX, a noncatalytic metalloproteinase fragment with integrin binding activity. Cell 1998, 92, 391-400. [CrossRef] 